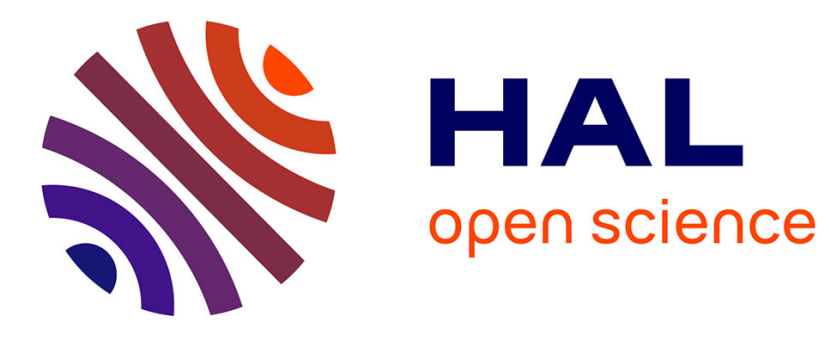

\title{
Skin and brain age together: The role of hormones in the ageing process
}

Evgenia Makrantonaki, Peter Schönknecht, Amir M. Hossini, Elmar Kaiser, Myrto-Maria Katsouli, James Adjaye, Johannes Schröder, Christos C.

Zouboulis

\section{To cite this version:}

Evgenia Makrantonaki, Peter Schönknecht, Amir M. Hossini, Elmar Kaiser, Myrto-Maria Katsouli, et al.. Skin and brain age together: The role of hormones in the ageing process. Experimental Gerontology, 2010, 45 (10), pp.801. 10.1016/j.exger.2010.08.005 . hal-00625924

\section{HAL Id: hal-00625924 \\ https://hal.science/hal-00625924}

Submitted on 23 Sep 2011

HAL is a multi-disciplinary open access archive for the deposit and dissemination of scientific research documents, whether they are published or not. The documents may come from teaching and research institutions in France or abroad, or from public or private research centers.
L'archive ouverte pluridisciplinaire HAL, est destinée au dépôt et à la diffusion de documents scientifiques de niveau recherche, publiés ou non, émanant des établissements d'enseignement et de recherche français ou étrangers, des laboratoires publics ou privés. 


\section{Accepted Manuscript}

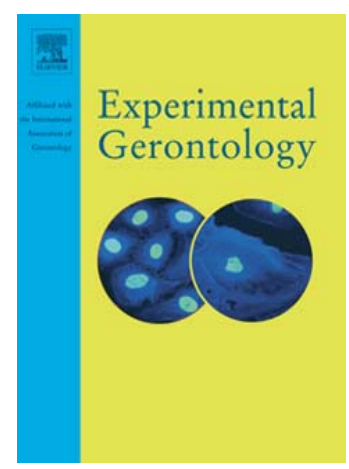

PII:

S0531-5565(10)00230-5

DOI: $\quad$ doi: $10.1016 /$ j.exger.2010.08.005

Reference: $\quad$ EXG 8770

To appear in: $\quad$ Experimental Gerontology

Received date: 20 March 2010

Revised date: $\quad 10$ August 2010

Accepted date: 10 August 2010

Please cite this article as: Makrantonaki, Evgenia, Schönknecht, Peter, Hossini, Amir M., Kaiser, Elmar, Katsouli, Myrto-Maria, Adjaye, James, Schröder, Johannes, Zouboulis, Christos C., Skin and brain age together: The role of hormones in the ageing process, Experimental Gerontology (2010), doi: 10.1016/j.exger.2010.08.005

This is a PDF file of an unedited manuscript that has been accepted for publication. As a service to our customers we are providing this early version of the manuscript. The manuscript will undergo copyediting, typesetting, and review of the resulting proof before it is published in its final form. Please note that during the production process errors may be discovered which could affect the content, and all legal disclaimers that apply to the journal pertain. 


\section{Skin and brain age together: The role of hormones in the ageing process}

Evgenia Makrantonaki ${ }^{1,2}$, Peter Schönknecht ${ }^{3}$, Amir M. Hossini ${ }^{1}$, Elmar Kaiser ${ }^{4}$, Myrto-Maria Katsouli $^{1,2}$, James Adjaye ${ }^{5}$, Johannes Schröder ${ }^{4}$, Christos C. Zouboulis ${ }^{1,2}$

${ }^{1}$ Departments of Dermatology, Venereology, Allergology and Immunology, Dessau Medical Center, Auenweg 38, 06847 Dessau, Germany

${ }^{2}$ Laboratory for Biogerontology, Dermato-Pharmacology and Dermato-Endocrinology, Institute of Clinical Pharmacology and Toxicology, Charité Universitaetsmedizin Berlin, Campus Benjamin Franklin, Garystrasse 5, 14195 Berlin, Germany

${ }^{3}$ Department of Psychiatry and Psychotherapy, University Hospital Leipzig, Semmelweisstrasse 10, 04103 Leipzig, Germany

${ }^{4}$ Section of Geriatric Psychiatry, Department of Psychiatry, Ruprecht Karls University of Heidelberg, Vossstrasse 4, 69115 Heidelberg, Germany

${ }^{5}$ Max Planck Institute for Molecular Genetics, Molecular Embryology and Aging Group, Ihnestrasse 63-73, 14195 Berlin, Germany

Running title: Hormonal ageing of skin and brain

Keywords: ageing, sex steroids, growth factors, skin, central nervous system, Alzheimer's disease

\section{Corresponding author:}

Prof. Dr. med. Christos C. Zouboulis

Departments of Dermatology, Venereology, Allergology and Immunology

Dessau Medical Center

Auenweg 38, 06847 Dessau, Germany

Tel: +49-340-5014000, Fax: +49-340-5014025

E-mail: christos.zouboulis@klinikum-dessau.de 


\begin{abstract}
The importance of the endocrine environment in the initiation of the ageing process has been elucidated in several in vivo an in vitro studies. Changes in endocrine pathways accompany healthy ageing, these include the growth hormone /insulin like growth factor-I axis (somatopause) and that of sexual hormones, namely estradiol (menopause), testosterone (andropause), and dehydroepiandrosterone and its sulphate (adrenopause). The clinical significance of these changes is variable and results in morphological and functional alterations of all organ systems including the skin and the central nervous system. Moreover, the pathogenesis of age-associated diseases such as epithelial skin cancer and neurodegenerative diseases has been partly attributed to the lack of hormones. Several studies have been conducted in an attempt to reverse the ageing process and clinical signs by substitution of the serum hormone levels in older individuals, however the benefits of hormone replacement therapy, if any, are still controversial. On the other hand, recent data suggest that skin is a window to the human organism and represents an adequate model for ageing research, also implying the use of skin samples for evaluating the ageing status of the central nervous system.
\end{abstract}




\section{Introduction}

Despite the progress in elucidating the genetic basis of longevity and ageing in many model organisms ranging from yeast and nematodes to mice, a large-scale, systematic approach for the exploration of ageing in humans is still at its infancy. So far, a variation in the gene apolipoprotein E (APOE) (Blanche et al., 2001; Christensen et al., 2006) and forkhead box O3A gene (FOXO3A) have been found to be consistently associated with longevity in various populations (Flachsbart et al., 2009; Willcox et al., 2008). Recently, stress response genes, particularly the heat shock protein HSP70 genes which are present within the MHC-III region on the short arm of chromosome 6 (Singh et al., 2007) and a functional EXO1 promoter variant have gained a lot of attention and have been shown to be significantly associated with human longevity and survival (Nebel et al., 2009).

With healthy ageing there are changes in endocrine pathways, including the growth hormone (GH) / insulin like growth factor-I (IGF-I) axis (somatopause) and that of sexual hormones, namely estradiol (menopause), testosterone (andropause), and dehydroepiandrosterone (DHEA) and its sulphate (DHEA-S) (adrenopause). GH is produced by somatotroph cells in the anterior pituitary. GH secretion is pulsatile, principally under the stimulatory influence of the hypothalamus via GH-releasing hormone, and is inhibited by somatostatin also produced in hypothalamus. GH secretion is relatively stable during childhood, increases during adolescence and decreases gradually during adulthood. This agerelated decline in $\mathrm{GH}$ secretion involves a number of changes in the $\mathrm{GH}$ axis, including decreased serum levels of IGF-I and decreased secretion of GH-releasing hormone from the hypothalamus. The cause of the normal age-related decrease in GH secretion is not well understood, but is thought to result in part from increased secretion of somatostatin, the GHinhibiting hormone, or from an age-related decrease in the number and size of somatotrophs. Moreover, the $\mathrm{GH}$ response to GH-releasing hormone is attenuated with advancing age (Corpas et al., 1993).

IGF-I is produced primarily by hepatocytes, but also by many other cells including chondrocytes, osteoblasts, epithelial breast cells, granulosa cells, melanocytes and dermal fibroblasts (Adashi et al., 1985; D'Ercole et al., 1984; Han et al., 1987; Tavakkol et al., 1992), where it may act in an autocrine or paracrine manner. Serum levels of IGF-I have been reported to increase from birth to puberty, followed by a slow decline through adulthood. This reduction is correlated with the progressive decline of GH with advancing age (Bennett et al., 1984) 
Steroidogenic organs include the adrenal cortex, the gonads and the placenta. All these tissues use cholesterol as the precursor for the formation of characteristic steroid hormones. Cholesterol synthesis and steroid hormone synthesis from cholesterol has been confirmed that also occur in the epidermis and the sebaceous glands (Menon et al., 1985; Smythe et al., 1998). Sex steroid secretion is under the stimulatory influence of luteinizing hormone (LH) and follicle stimulating hormone (FSH), both derived from the pituitary and regulated by a decapeptide, the gonadotropin-releasing hormone $(\mathrm{GnRH})$, synthesised in the hypothalamus.

DHEA and DHEA-S are the most abundant steroids in the human plasma having serum concentrations in the order of $10^{-8}$ and $10^{-6} \mathrm{M}$, respectively. In adult men and women, serum DHEA-S levels are 100 to 500 times higher than that of testosterone and are 1,000 to 10,000 times higher than that of estradiol (Labrie et al., 1998). The DHEA /DHEA-S concentrations in serum reach a peak between the ages of 25 and 30 years and thereafter decline steadily, so that by the age of 60 , serum concentrations are only $5-10 \%$ of corresponding values in young adults (Orentreich et al., 1984). This decline in women appears to be primarily a function of age and seems to be unrelated to menopause status (Burger et al., 2000).

In males, over $95 \%$ of the testosterone is secreted by the testicular Leydig cells; the remainder is derived from the adrenals. In addition to testosterone, the testes secrete small amounts of the potent androgen $5 \alpha$-dihydrotestosterone ( $5 \alpha$-DHT). In females, small amounts of testosterone are also produced by the ovaries and are released into the circulation as precursors of estrogen synthesis as well as to act on peripheral tissues. The secretion of testosterone displays a diurnal rhythm (Faiman and Winter, 1971). Serum testosterone levels in men decrease with age (Gray et al., 1991; Harman et al., 2001). It has been shown that 20\% of healthy men in their sixties and $30 \%$ of men in their seventies have lower testosterone levels than $97.5 \%$ of healthy 20 - to 45 -year old men (Harman et al., 2001). Feldman et al. found that total testosterone levels decreased by $0.8 \%$ per year while bioavailable testosterone fell by $2 \%$ per year and sex hormone binding globulin levels increased by $1.6 \%$ per year (Feldman et al., 2002). These changes are due in part to a reduction in the number of Leydig cells in the testes that produce testosterone.

The ovary is normally the major source of estrogens, although the conversion of androgen precursors to estrogens in other tissues such as skin is clinically important after the menopause. In males, small quantities of estrogens such as estradiol, estrone and progesterone are produced by the Leydig cells of the testes. However, estradiol is not only derived by direct 
secretion from the testes but also by conversion in peripheral tissues of estrogen precursors secreted both by the testes and the adrenals. Thus, about $80 \%$ of the circulating concentrations of estradiol is derived from peripheral conversion. In women, estrogen levels decline rapidly at menopause as a result of the loss of ovarian follicles (Smyth et al., 1994), whereas in men the levels of estrogens remain unchanged.

The effects of the observed hormone decline are gradually reflected on our skin, however internal organs such as the central nervous system (CNS) are also affected by the changing endocrine conditions (Bishop and Simpkins, 1995; Fernandez-Tresguerres Hernandez, 2004; Hollis et al., 2009; Lustig, 1994). Dementia - a hallmark of the ageing CNS has been partially attributed in several studies to the lack of circulating hormones. It is estimated that worldwide 24 million people suffer from dementia. By 2040, this number is projected to increase to 81 million people (Ferri et al., 2005). The most frequent cause of dementia is Alzheimer's disease (AD) (more than 60\%) (Qiu et al., 2007). Associated with these numbers is not only human suffering but also enormous costs which go towards the maintenance of a certain level of life quality and the treatment of comorbidities.

This review article attempts to delineate some aspects of the interaction between the regulation of endocrine function and the ageing process and explores the age-related changes in hormone metabolism and production, with their clinical consequences on the physiology of two tissues with common embryology, the skin and the CNS. The pathogenesis of ageassociated disorders such as skin and neurodegenerative diseases, particularly with a focus on $\mathrm{AD}$, and their connection with hormones will be discussed. In addition, evidence will be provided that skin may be used as a valuable in vitro model for studies on $\mathrm{AD}$ and for development of potential therapies.

\section{Skin ageing}

Regarding the pathogenesis of aged skin, several theories have been proposed including the theory of cellular senescence (Dimri et al., 1995; Gilchrest, 1983; Hayflick, 1965; Schneider and Mitsui, 1976; Tresini et al., 2007), decrease in cellular DNA repair capacity and loss of telomeres (Allsopp et al., 1992; Bodnar et al., 1998; Kosmadaki and Gilchrest, 2004; Smith and Pereira-Smith, 1996), point mutations of extranuclear mtDNA (Michikawa et al., 1999), oxidative stress (Miquel, 1998), increased frequency of chromosomal abnormalities (Benn, 1976; Ly et al., 2000), single gene mutations 
(Makrantonaki and Zouboulis, 2007a) and hormones (Makrantonaki et al., 2008; Makrantonaki and Zouboulis, 2009; Zouboulis et al., 2007; Zouboulis Ch, 2003).

In contrast to extrinsic skin ageing, which is an organ specific event influenced by environmental factors [e.g. ultraviolet (UV)/infrared radiation] mostly affecting sun-exposed areas of the body, such as face, neck, arms and hands, intrinsic skin ageing is influenced by the individual genetic predisposition and affects both exposed and non-exposed areas of the body (e.g. inner side of the upper arm). Intrinsically aged skin is characterised by smoothness, dryness, pale color and fine wrinkling (Gilchrest, 1982), whereas extrinsically aged skin shows specific histological changes and is clinically characterised by deep wrinkles and multiple pigmentary changes [reviewed in (Makrantonaki and Zouboulis, 2007c)].

During the last decade, the rapid development of genomics, proteomics, metabolomics and bioinformatics has enabled a comprehensive assessment of skin ageing at the fundamental levels of gene and protein expression as well as their downstream metabolic processess has helped us to identify important biomarkers of skin ageing. Gene expression patterns compatible with mitotic dysregulation and alterations in intracellular transport and metabolism were identified in fibroblasts of ageing humans and afflicted with progeria (Ly et al., 2000). Lener et al. investigated the gene expression profiles of young and aged human foreskin via cDNA microarrays. The mechanisms proposed to be involved in the induction of skin ageing comprise disturbed lipid metabolism, altered insulin and STAT3 signalling, upregulation of apoptotic genes partially due to the dysregulation of FOXO1, downregulation of members of the jun and fos family, differential expression of cytoskeletal proteins (e.g., keratin 2A, 6A, and 16A), extracellular matrix components (e.g., PI3, S100A2, A7, A9, SPRR2B), and proteins involved in cell-cycle control (e.g., CDKs, GOS2) (Lener et al., 2006). Gene expression profiling was also examined in sun-protected (buttocks) and sunexposed skin (extensor forearm) from 10 young (age 19 to 20 years) and 10 aged women (age 63 to 67 years) in order to examine gene expression profiles associated with chronological skin ageing and photoageing. Both chronologic ageing and photoageing were associated with downregulation of the biological process of lipid synthesis. In particular, genes were downregulated involved in the cholesterol and fatty acid synthesis. A global reduction in skin surface lipids and a profound abnormality in cholesterol synthesis have been already described in aged skin and correspond to the above results (Elias and Ghadially, 2002). In addition, genes associated with epidermal differentiation, including keratin filaments and cornified envelop components were downregulated. An upregulation of the biological processes of inflammatory response and wound healing, the molecular functions of cytokine 
activity and protease activity and the cellular component theme of extracellular matrix was also observed in both skin ageing types. The elastin gene expression was upregulated with ageing only in the photodamaged arm and remained unchanged in the sun-protected buttock. This finding corresponds to the histopathological findings which show typical elastotic changes the so called 'solar elastosis' in photoaged skin (Robinson et al., 2009).

Advanced age is associated with a hyper-inflammatory state, referred to as inflamm-ageing (Franceschi et al., 2000). The immune system of aged animals and humans undergoes alterations that may account for an increased susceptibility to certain infections, autoimmune diseases, and malignancies (Linton and Dorshkind, 2004; Plackett et al., 2004; Plowden et al., 2004). The number or function of T cells and B cells deteriorate (Effros, 2001; Gardner and Murasko, 2002; Grubeck-Loebenstein and Wick, 2002) while the effects of age on innate immune cells, such as macrophages have been widely investigated (Plackett et al., 2004). In human skin, cytokine dysregulation, particularly of the interleukin (IL)-1 family has been described to contribute to ageing (Ye et al., 2002) and disturbed skin barrier function. The microinflammatory model of skin ageing postulates that every stimulus able to induce the synthesis of intercellular adhesion molecule-1 (ICAM-1) in the endothelium is a factor of skin ageing. ICAM-1 favours the diapedesis and the recruitment in the dermis of circulating immune cells, which in turn release reactive oxygen species and proteolytic enzymes which digest structural fibers and provoke damages to resident cells (Giacomoni and Rein, 2004; Goyarts et al., 2007).

\subsection{Effects of hormones on skin ageing}

Ageing is associated with physiological changes of the endocrine glands as a result of programmed cell death, autoimmune-mediated destruction of the gland or neoplastic transformation of glandular tissue. Consequently, hormone secretion is reduced and secondary physiological changes in circadian and seasonal rhythms or in the frequency or the height of hormone pulses are observed (Mooradian, 1993b). In a recent study, the age-related decline of progenitor cell activity of mice could be reversed by exposure to young serum and the cells could retain much of their intrinsic proliferative potential even when they become old, underlining the great importance of the systemic environment (Conboy et al., 2005). Hence, the importance of the endocrine system and the circulating hormones has currently begun to gain more attention. 


\subsubsection{Sex steroids}

Among the multiple functions of the skin, synthesis of sex steroids has been elucidated in several studies in vitro. The production of sex steroids depends upon the expression of the androgen- and estrogen-synthesising enzymes in each cell type, with sebaceous glands and sweat glands being the major contributors. Skin has the ability to use cholesterol for the formation of epidermal barrier and, in extreme hormone insufficiency, also sebum. One of the key enzymes, cytochrome P450c17, which is necessary for synthesis of dehydroepiandrosterone and androstenedione, has been documented to be expressed in human sebocytes. These androgenic pro-hormones can be further converted by sebocytes and sweat glands, and probably also by dermal papilla hair cells, into more potent androgens, such as testosterone and 5a-DHT (Makrantonaki and Zouboulis, 2009; Zouboulis et al., 2007). In addition, the enzyme aromatase may convert testosterone and androstenedione to estrogens in sebaceous glands, outer as well as inner root sheath cells of anagen terminal hair follicles, and dermal papilla cells (Fritsch et al., 2001; Thornton et al., 2006).

During the decline of the circulating hormones with age, the skin partially overtakes the function of the gonads, regarding the synthesis of sex hormones, however, for a definite period of time only. The imbalances between androgen and estrogen levels that occur may be responsible for the observed skin alterations and indirectly for several age-associated diseases (Zouboulis, 2000) [Figure 1]. The typical skin phenotype accompanying menopause has been attributed to hypoestrogenism in several studies. Brincat et al. demonstrated a significant decrease in skin thickness and amount of dermal collagen in the initial postmenopausal years and this reduction correlated to a reduction in bone mineral density (Brincat, 2000). This observation has been confirmed in further studies showing that collagen content in the dermis and especially the production of type I and III collagen as well as the type III/I ratio decrease with age (Affinito et al., 1999). In addition, postmenopausal women not receiving replacement therapy are more likely to experience dry skin and develop wrinkles in comparison with those under estrogen substitution (Dunn et al., 1997). Skin elasticity is also decreased and changes in the number and morphology of elastic fibers have been observed in women after menopause (Punnonen et al., 1987; Sumino et al., 2004).

In an animal study, the skin phenotypes of aromatase-knockout hairless (ArKO) mice and wild-type hairless (WT) mice were documented and they were compared with those of ovariectomised (OVX) and control (Sham) mice. ArKO and OVX mice similarly exhibited a deterioration of skin properties as compared to their respective controls illustrating the importance of estrogens for maintaining skin homeostasis. This deterioration was amplified 
by chronic UVB irradiation. Furthermore, while the skin of ArKO mice showed no reaction after an acute UVB irradiation at dose intensities which could cause sunburn, a follow-up observation revealed delayed reactions associated with brownish skin colour and swelling only in this type of mice. This finding demonstrates the role of extragonadal estrogens in the protection of skin (Tsukahara et al., 2008).

In in vivo studies, topical or oral application of estrogens have been correlated with beneficial effects on skin parameters in postmenopausal women. Amongst them improvement of skin dryness, wrinkles and increase of epidermal thickness have been described (Schmidt, 2005). Interestingly, local $17 \beta$-estradiol can only induce procollagen I and III and collagen I in light-protected but not in light exposed skin (Rittie et al., 2008). In in vitro experiments, $17 \beta$-estradiol can significantly induce the proliferation of human dermal fibroblasts (Makrantonaki et al., 2008) and the production of collagen and this effect has been attributed to regulation of transforming growth factor (TGF)- $\beta$ (Ashcroft et al., 1997; Chau et al., 1998). Furthermore, estradiol induces the proliferation and DNA synthesis of keratinocytes. Apart from the known estrogen receptors (ER) $\alpha$ and $\beta$, new described estrogen-binding entities, e.g. in the plasma membrane or the endoplasmic reticulum may contribute to this action (Kanda and Watanabe, 2005). Even the existence of a third ER, ER $\gamma$, is being discussed (Hawkins et al., 2000). Recently, we demonstrated that fibroblasts are more susceptible to $17 \beta$-estradiol in contrast to human sebocytes and the observed effects of estrogens in vivo may be implemented through an interaction with the IGF-I signalling pathway (Makrantonaki et al., 2008) in human skin cells.

Furthermore, estrogens have been shown to act as anti-inflammatory agents. Reduced levels of estrogens observed in postmenopausal women have been associated with disturbed effects on tissue regeneration through impaired cytokine transduction, altered protein balance and uncontrolled inflammation. In in vitro studies estrogens downregulate the production of the neutrophil, type $1 \mathrm{~T}$ cell and macrophage-attracting chemokines, CXCL8, CXCL10, CCL5, by keratinocytes, and suppresses IL-12, TNF $\alpha$ production and antigen-presenting capacity while enhancing anti-inflammatory IL-10 production by dendritic cells reviewed in (Kanda and Watanabe, 2005). In ovariectomised young female rodents, topical application of estrogens on skin can significantly accelerate the wound healing process and is accompanied by an activation of the TGF $\beta$ signalling pathway (Ashcroft et al., 1997). Estrogens inhibit the expression of the macrophage migration inhibitory factor influencing the initiated local inflammation (Ashcroft and Ashworth, 2003) and they preferentially induce dermal cellular expression of ER $\beta$ within the wound indicating the importance of ER $\beta$ in wound healing 
(Gilliver and Ashcroft, 2007). Systemic treatment of 10-week old ovariectomised C57/B16 mice and of 10-week C57/B16 mice with intact ovaries with selective estrogen receptor modulators (SERMs), e.g. tamoxifen or raloxifene, after injury may result in a statistically significant acceleration of healing, reduced wound areas, and accelerated reepithelialisation (Hardman et al., 2007). Both SERMs inhibit wound expression of the pro-inflammatory cytokines MIF, IL6 and TNF in wounds from ovariectomised mice, indicating antiinflammatory activity. In healthy elderly men and women topical estrogens significantly induce the expression of fibronectin on cutaneous ulcerations and decrease elastase levels secondary to reduced neutrophil numbers resulting in a rapid progress of wound healing. In contrast, male sex hormones especially endogenous testosterone inhibit skin wound healing response in males (Gilliver et al., 2007). Smad3 plays a crucial role in mediating androgen signalling (Ashcroft et al., 2003) and is associated with an enhanced inflammatory response. It is not by coincidence that elderly males show a slower healing process in comparison with their age-matched female counterparts (Makrantonaki and Zouboulis, 2009).

Dehydroepiandrosterone (DHEA) seems to play a key role in the synthesis of extracellular matrix and its decline with age may lead to a decrease in procollagen synthesis and enhancement of collagen degradation by increasing matrix metalloproteinases (MMP)-1 and collagenase synthesis whilsts decreasing tissue inhibitor of matrix metalloprotease (TIMP)-1 and stromelysin-1 production (Lee et al., 2000; Shin et al., 2005). In a double-blind, placebocontrolled study conducted with 280 elderly healthy individuals, $50 \mathrm{mg}$ DHEA was given orally daily over one year. Apart from several benefits described, e.g. in bone turnover and increase in libido parameters, the skin status was significantly improved particularly in women, in terms of hydration, epidermal thickness, sebum production, and pigmentation (Baulieu et al., 2000). However, this study did not include an effective long-term evaluation.

Androgens are a major stimulus of sebaceous gland differentiation and sebum production, while estrogens directly suppress human sebum secretion (Guy et al., 1996; Pochi et al., 1979). However, despite clinical evidence that androgens stimulate sebaceous lipid synthesis, experiments in vitro could not confirm a direct androgen effect on sebocyte lipogenesis. Current studies could elucidate this discrepency: the lipogenic effect of testosterone in vivo is regulated by co-factors such as peroxisome-proliferator activated receptor (PPAR) ligands. PPARs regulate multiple lipid metabolic genes in mitochondria, peroxisomes and microsomes, all prominent in the cytoplasma of sebocytes (Chen et al., 2003; Rosenfield et al., 1998). In human sebocytes the combination of testosterone and the natural PPAR- $\alpha / \delta$ ligand linoleic acid, an essential fatty acid, exhibits a synergistic effect on lipid synthesis and 


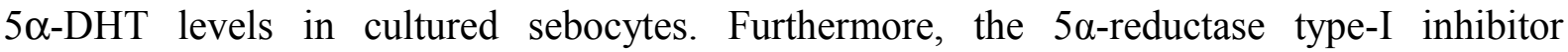
LY191704 may only unfold its action under concurrent cell exposure to both compounds. These data suggest a catalytic PPAR effect on cellular testosterone activation and discover a new mode of androgen involvement in sebum production (Makrantonaki and Zouboulis, 2007b). Further studies are needed to elucidate whether the expression of PPARs is altered in advanced age.

Hormone replacement therapy has been correlated with enhancement of collagen production, increase in skin thickness, surface lipids, hydration, vascularisation and increase of the hair follicle life cycle (Brincat, 2000; Callens et al., 1996; Fuchs et al., 2003; Patriarca et al., 2007; Sator et al., 2007; Sator et al., 2001) leading to an improvement of skin tone and appearance. Hormone replacement may only improve the skin quality in female patients treated during the first 24 months after menopause (Phillips et al., 2008) (Table I).

However, further investigations are warranted to determine the appropriate timing of treatment and the effective concentrations of estrogens that can be used without the reported systemic risks (Beral, 2003): In a study consisting of two parallel randomised, double-blind, placebo-controlled clinical trials of hormone therapy to determine whether conjugated equine estrogen alone or in combination with progestin would have any beneficial effects, increased risks of breast cancer, coronary heart disease, stroke and pulmonary embolism were documented in the estrogen / progestin group (Rossouw et al., 2002).

\subsubsection{Growth factors}

The GH / IGF-I axis is considered to be one of the most important signalling pathways associated with ageing. Its relevance to the skin can be observed in patients with isolated GH deficiency, multiple pituitary hormone deficiency including GH, as well as primary IGF-I deficiency (GH resistance, Laron syndrome) which present signs of early skin ageing, such as dry, thin and wrinkled skin. Other resulting characteristics of GH / IGF-I deficiency are obesity, hyperglycemia, reduced body lean mass, osteopenia, lowered venous access, hypercholesterolemia, cardiovascular diseases and, subsequently, premature mortality (Carroll et al., 1998; Laron, 2005; Tomlinson et al., 2001; Zouboulis et al., 2007) (Table II). These features can be reversed by long-term hormone replacement therapy with recombinant human GH (Carroll et al., 1998). This has led to the suggestion that the elderly with low levels of GH would benefit from GH treatment.

On the other hand, the increased serum GH levels in acromegaly has been associated with enhanced sebum secretion (Burton et al., 1972) an observation that could be confirmed by GH 
treatment of human SZ95 sebocytes in vitro (Makrantonaki et al., 2008). In Mini rats, suppression of GH gene expression by an antisense transgene resulted in thinner skin with less collagen, increase of subcutaneous adipose tissue and small-sized sebaceous glands (Ikawa et al., 2002).

Moreover, IGF-I has been shown to stimulate sebocyte differentiation in vitro especially in combination with GH (Deplewski and Rosenfield, 1999), while in human keratinocytes it acts as a mitogen (Tavakkol et al., 1999). In acne vulgaris, increased sebum production peaks in mid-adolescence at a time that GH and IGF-I reach their highest serum levels (Deplewski and Rosenfield, 1999). IGF-I amplified lipid synthesis in SZ95 sebocytes and fibroblasts as well as fibroblast proliferation, all in a dose-dependent manner underlining the fact that the declining IGF-I levels with increasing age may play a significant role in the reduction of skin surface lipids and thickness (Makrantonaki et al., 2008). Furthermore, it has been shown that there is diminished IGF-I expression in aged skin and this correlates with an inappropriate UVB response in elderly volunteers. The appropriate UVB response can be restored in aged skin in vivo through pre-treatment with exogenous IGF-I. These results imply that reduced expression of IGF-I in aged skin could be an important component in the development of aging-related non-melanoma skin cancer (Lewis et al., 2009).

Treatment of normal elderly males with GH has been documented to ameliorate and reverse the ageing signs and symptoms. After 6 months treatment of recombinant GH in 12 healthy 61- to 81-year-old men who exhibited serum IGF-I concentrations below those of young men resulted in increased lean body mass, decreased adipose-tissue mass, increased average lumbar vertebral bone density and increased skin thickness (Rudman et al., 1990). However, the study was not double-blind and lacked assessment of muscle strength, exercise endurance or quality of life (Vance, 2003). In addition, the observed increase in lean body mass and skin thickness may be due to increased body water (Marcus and Hoffman, 1998). On the other hand, GH supplementation did not result in the improvement of functional parameters (Papadakis et al., 1996). Co-administration of low dose GH with testosterone resulted in more beneficial changes amongst them increased lean body mass, midthigh muscle, muscle strength, aerobic capacity and decreased body fat (Giannoulis et al., 2006). Recent reports of an association of GH substitution with increased risk of prostate, lung, colon and breast cancer as well as a possible improvement of insulin insensitivity make further investigations necessary regarding safety and efficacy of GH substitution in the ageing population (Riedl et al., 2001). 
Injectable recombinant human IGF-I (mecasermin) has been available for nearly 20 years for treatment of the rare instances of GH insensitivity caused by GH receptor defects or GHinhibiting antibodies. Other applications that have been considered or are under investigation are based on the beneficial effects of IGF-I on burns, wound healing, Werner syndrome, Alzheimer's disease (Carro et al., 2006), bone mass, muscular dystrophy (Boonen et al., 2002), amyotrophic lateral sclerosis, spinal cord injury (Hollis et al., 2009), cardiovascular protection and diabetes (Rosenbloom, 2009). However, side effects such as hypoglycemia, hyperplasia of lymphoid tissue accumulation of body fat and coarsening of the face have been described after IGF-I application (Chernausek et al., 2007; Guevara-Aguirre et al., 1997; Guevara-Aguirre et al., 1995). In addition, the anti-apoptotic effects of IGF-I are also a concern for long-term therapy as it may result in cancer induction (Samani et al., 2007).

Recently, clinical studies have documented that sex-steroid hormones can regulate GH and IGF-I secretion. Supplementation of middle-aged and older men with high-dose testosterone attenuated IGF-I feedback-dependent inhibition of GH secretion (Veldhuis et al., 2004), whereas acute administration of estradiol accentuated IGF-I-induced inhibition of GH secretion (Veldhuis et al., 2004). The reduction of circulating sex steroids, which occurs with advancing age, can therefore lead to a defective regulation of both growth factors.

\section{CNS and ageing - Cerebral and molecular changes in neurodegenerative diseases}

$\mathrm{AD}$ is a progressive neurodegenerative disorder with gradual onset and deterioration of cognitive functions such as memory, language and visio-spatial skills (Schonknecht et al., 2005). The clinical diagnosis of AD necessitates exclusion of other forms of dementia such as vascular dementia or dementia due to cerebral neoplasm, inflammation or other pathologies. Histopathologically, AD is associated with neurofibrillary tangle formation and deposition of amyloid plaques in susceptible brain regions. Tau protein, a microtubule-associated protein, seems to be released into the cerebrospinal fluid (CSF) during neurofibrillary tangle formation and has been found to be increased in patients with manifest AD (Schonknecht et al., 2003) as well as in mild cognitive impairment or incipient AD (Schonknecht et al., 2007).

A major feature of $\mathrm{AD}$ is the presence of amyloid plaques in the brain. Amyloid plaques are extracellular deposits of fibrillar aggregates mostly composed of a $4 \mathrm{kDa}$ peptide, $\beta$ amyloid 1-42 (A $\beta 42)$, which is derived along with the peptide $\beta$-amyloid 1-40 (A $\beta 40)$ from the larger amyloid precursor protein (APP) by proteolytic cleavage (Jensen et al., 1999). Several studies have indicated that the deposition of $A \beta 42$ constitutes an important process in 
the aetiology of neuronal degeneration, and CSF A $\beta 42$ concentrations have been shown to be a sensitive marker of AD pathology (Ida et al., 1996).

Neuroimaging studies have demonstrated that cerebral changes characteristic of AD primarily strike the temporal lobe with a particular focus on medial temporal substructures. These cerebral changes may be reliably assessed using quantitative magnetic resonance imaging (Pantel et al., 1999).

Several studies have indicated that both genetically determined disturbances in APP metabolism with consecutive overexpression of the protein and a pathological enzymatic processing of APP to A $\beta$ are essentially involved in the production of amyloid plaques. The $\mathrm{A} \beta$ release, however, has been proposed to be modified by several co-factors such as metals (copper, zinc), apolipoprotein E, cholesterol and oestrogens.

In order to identify age-associated changes of the cholesterol metabolism, healthy elderly were compared with patients with $\mathrm{AD}$ with respect to serum and CSF levels of cholesterol and its major metabolites (Schonknecht et al., 2002). Experiments in cell cultures indicated earlier, that accumulation of cholesterol in hippocampal neurons results in an accelerated cleavage of amyloid precursor protein into amyloidogenic components which leads to formation of amyloid plaques in susceptible brain regions of $\mathrm{AD}$ patients. Cholesterol is converted to $24 \mathrm{~S}$-hydroxycholesterol by cholesterol $24 \mathrm{~S}$-hydroxylase prior to be eliminated from the brain. Since plasma 24S-hydroxycholesterol levels are strongly influenced by hepatic clearance it was hypothesized that only CSF 24S-hydroxycholesterol may be an appropriate indicator of cholesterol turnover of the brain than its plasma concentration, differentiating it from age-associated changes. Since epidemiological evidence indicated that serum cholesterol levels are altered in AD and in studies on 24S-hydroxycholesterol this presents a potential bias, CSF 24S-hydroxycholesterol levels in AD patients and controls were investigated in subjects with plasma cholesterol levels in a normal range (Schonknecht et al., 2002). CSF and plasma samples were obtained from twenty-five patients with probable AD as part of the routine diagnostic procedure and nineteen patients without cognitive deficits nor psychiatric or neurological disorders who received lumbar anesthesia for surgery. 14 samples from $\mathrm{AD}$ patients and 10 from controls with plasma cholesterol levels in the normal range between $150-230 \mathrm{mg} / \mathrm{dl}$ were selected. CSF samples were drawn in the morning before noon, immediately aliquoted and frozen at $-80{ }^{\circ} \mathrm{C}$. Light microscopy was performed to exclude any probes contaminated with erythrocytes. CSF and plasma 24S-hydroxycholesterol and CSF cholesterol levels were measured using combined gas chromatography and mass spectrometry. In the AD patients, CSF 24S-hydroxycholesterol - but not plasma levels - were 
significantly increased compared to the controls. Neither total CSF cholesterol nor total plasma cholesterol levels differed significantly between groups. Repeated analyses with BMI entered as a covariate revealed consistent results. Within the AD group, no significant correlation between 24S-hydroxycholesterol CSF levels and age, age of onset, severity of dementia, BMI nor plasma cholesterol nor significant differences with respect to medication status arose. To address potential effects of the ApoE genotype, a two-way analysis of variance with diagnosis and ApoE genotype as main factors was calculated. Again, a significant effect of diagnosis with significantly increased CSF 24S-hydroxycholesterol values in the $\mathrm{AD}$ patients emerged. Based on these findings it may be summarized that an increase of CSF 24S-hydroxycholesterol levels is rather due to AD pathology and that this effect is not triggered by plasma cholesterol which may be normal in the patients as in the healthy elderly. However, a significant correlation between CSF tau protein concentrations and CSF 24S-hydroxycholesterol levels did not arise indicating that changes in the cholesterol metabolism in AD may not fully parallel AD pathology.

As in skin ageing, inflammatory processes have been also discussed in the pathophysiology of AD (Tan and Seshadri, 2010). This has recently been investigated in a study by van Exel et al. (2009) who used known risk factors of AD to identify high- and lowrisk samples in whom they compared levels of inflammatory risk factors (van Exel et al., 2009). In contrast to blood-borne ions, molecules, and cells, only peripheral blood monocytes and macrophages may actively cross the blood-brain barrier and hence better reflect CNS inflammation. This might explain why large population-based studies failed to relate circulating levels of inflammatory markers such as CRP to risk of AD. Nevertheless, the Framingham Study reported an association between increased cytokines (IL-1 and tumor necrosis factor-alpha) in peripheral blood monocytes and an approximately twofold increase in risk of incident AD (Tan et al., 2007). This finding is in accordance with van Exel at al. (2009) who demonstrated that middle-aged persons with a parental history of late onset AD show adverse levels of vascular risk factors such as higher blood pressures and a lower anklebrachial index, as well as an increase of proinflammatory cytokines in lipopolysaccharidestimulated whole blood samples when compared with middle-aged subjects without a parental history of AD. Interestingly, this association was independent of the APOE genotype.

The mechanisms how cytokine dysregulation may injure neurons include an altered neurotransmission, apoptosis, and activation of microglia and astrocytes, followed by an increase of free radicals, complement factors, glutamate, or nitric oxide (Wilson et al., 2002). This has been emphasized by postmortem studies of AD brains which demonstrated CRP, 
proinflammatory cytokines, and activated complement cascade proteins in plaques and neurofibrillary tangles (Duong et al., 1997; Iwamoto et al., 1994). In addition to $\beta$-amyloid, IL-1 has been demonstrated to increase neuronal tau phosphorylation (Li et al., 2003). Todate, it remains unclear whether these proinflammatory cytokines are etiopathologically involved in or merely are a result of the $\mathrm{AD}$ cascade. The present findings, however, emphasize, at least, that inflammation may amplify the disease process of AD.

Based on this assumption, therapeutic effects of anti-inflammatory drugs have been expected in $\mathrm{AD}$. However, a recent meta-analysis failed to observe any association of either the serumamyloid lowering (SALA) or the non-SALA NSAIDs with a lower risk of AD as did randomized placebo-controlled clinical trials (for review see Tan and Seshadri, 2010). Again, the recent finding by van Exel et al. (2009) indicate the possibility of an therapeutic impact of any longer anti-inflammatory intervention than those investigated (van Exel et al., 2009). This is in accordance with the observation that higher blood pressures may act together with increased inflammation to enhance the risk for AD. One may conclude by the present findings that future studies of anti-inflammatory interventions should be undertaken in high risk populations of $\mathrm{AD}$, such as positive family history, at least one APOE $\varepsilon 4$ allele, or progressive MCI (Schonknecht et al., 2005).

\subsection{Effects of hormones on CNS and B-amyloid metabolism}

Although the fundamental mechanisms are still poorly understood, a growing body of evidence points towards age-related hormone decline as one of the primary determinants of the initiation of $\mathrm{AD}$. Among other potential benefits of long-term hormone replacement therapy such as the prevention of osteoporosis, atherosclerotic cardiovascular diseases and amelioration of the skin phenotype, there has been considerable interest in the potential of estrogens to be protective against the risk of developing neurodegenerative diseases, e.g. AD (Tang et al., 1996; Yaffe et al., 1998) (Table III).

\subsubsection{Sex steroids}

Estrogens can readily pass the blood-brain barrier and have several effects on the CNS (Henderson, 1997). They enhance the outgrowth of neurites and promote the formation of dendrite spines and synapses (Lustig, 1994; Woolley and McEwen, 1994). In the brain, estrogens increase cerebral blood flow and glucose metabolism and modulate acetylcholine metabolism (Bishop and Simpkins, 1995; Luine, 1985; Ohkura et al., 1995). Furthermore, the beneficial effect of estrogens on the CNS may be mediated by cholesterol and apo $\mathrm{E}$ 
metabolism since estrogens have been found to decrease serum cholesterol and apo E levels (Urabe et al., 1996) in postmenopausal women. In addition, oestrogens have been characterised as having an important impact on $\mathrm{A} \beta$ formation in the CNS, a hallmark of AD. Experiments in cell cultures revealed that physiological concentrations of $17 \beta$-estradiol increases the production of soluble APP at the expense of A $\beta 40$ and A $\beta 42$ production. Jaffe et al. demonstrated in-vitro that physiological concentrations of $17 \beta$-estradiol may modulate APP metabolism by increasing the cellular release of the soluble, non-amyloidogenic components (Jaffe et al., 1994). Xu et al. investigated the effect of physiological concentrations of $17 \beta$-estradiol on the APP metabolism of neurites and not only found an increase of soluble APP components but also significantly reduced A $\beta 42$ and $A \beta 40$ concentrations (Xu et al., 1998).

Moreover, animal studies have shown that prolonged ovariectomy results in uterine atrophy and decreased serum $17 \beta$-estradiol levels, and is associated with increased cerebral A $\beta$ levels (Petanceska et al., 2000). In the same study, 17ß-estradiol treatment significantly reversed the ovariectomy-induced increase in brain $A \beta$ levels.

The effect of estrogens on $A \beta$ metabolism may be mediated by a morphological modification of the intracellular trans-Golgi compartments where maturated APP is processed to A $\beta$. Furthermore, estrogens support neuronal APP transport and act against the apparent dysregulation which leads to increased $A \beta$ production (Xu et al., 1998). The protective effects of estrogens may also be mediated by interactions not directly related to APP processing such as modulation of neural functioning or prevention of oxidative toxicity due to glutamate, free radicals, and $\mathrm{A} \beta 40$ or $\mathrm{A} \beta 42$ (Mooradian, 1993a). Behl et al. showed that 17ß-estradiol can prevent intracellular peroxide accumulation and, ultimately, the degeneration of hippocampal neurons (Behl et al., 1997). To date, little is known about potential differential effects of the various estrogens on the CNS. The majority of studies have focused on 17 $\beta$-estradiol, which is generally considered to be the most potent estrogen. While some studies also addressed estrone, other estrogens, such as estriol or progestagens, such as progesterone have not been studied.

Taken together, data from studies investigating the potential role of estrogens as a beneficial agent for the cause and progression of $\mathrm{AD}$ in women appear rather conflicting. The Women's Health Initiative study for instance showed that estrogen therapy alone or in combination with progestin treatment increased the risk of both dementia and mild cognitive impairment (Shumaker et al., 2004). Since basic studies of the mechanisms of neurodegenerative disorders suggest at least two phases in their pathogenesis namely as 
initiation and propagation it was hypothesised that estrogens may interact differentially in each phase (Johnson et al., 1998). Dosage form, or doses required and specific type of estrogen may influence hormone substitution treatment effects on initiation and propagation of AD. Nevertheless, the impact of age, early onset and severity of dementia, and of longerterm treatment on the potential beneficial effects of hormone substitution treatment has still to be addressed.

\subsubsection{Growth factors}

It has been speculated that neuropeptides also play an important role in the development of $\mathrm{AD}$ due to their action as neuromodulators in the CNS (Guroff, 1993). Among them insulin-like growth factors (IGFs) are produced in the brain and act as trophic factors in the CNS. More specifically, IGF-I and IGF-II are known to play an important role in the regulation, differentiation and proliferation of numerous peripheral and central tissues (Masters and Raizada, 1993). Secretion of IGF-I is mainly regulated by GH but also by other hormones, such as glucocorticoids (Tham et al., 1988).

Interestingly, in $\mathrm{AD}$, neurofibrillary tangles accumulate in hypothalamic regions which are associated with the regulation of pituitary hormones (Thienhaus et al., 1987). A number of authors have proposed that neurocognitive decline might be promoted by a dysregulation of the hypothalamic-pituitary-gonadal (HPG) axis with menopause and andropause (Atwood et al., 2005), since dysregulation of the axis leads to alterations in the concentrations of all serum HPG hormones (decreased neuronal sex steroid signalling, but increased neuronal gonadotropin releasing hormone, luteinizing hormone, and activin signalling).

Mustafa et al. determined plasma IGF-I levels in family members carrying the Swedish amyloid precursor protein (APP) 670/671 mutation with or without AD and in agematched controls from the same family. They only found a significant reduction in the family members with $\mathrm{AD}$ compared to age-matched controls. Levels of $\mathrm{GH}$ and prolactin did not differ significantly between the mutation carriers with or without $\mathrm{AD}$ and their respective agematched controls (Mullan et al., 1992; Mustafa et al., 1999).

High levels of $\beta$-amyloid have been found at an early stage in mutant mice with low circulating IGF-I, and $\beta$-amyloid burden can be reduced in ageing rats by increasing serum IGF-I. IGF-I seems to induce clearance of brain $\beta$-amyloid, probably by enhancing transport of $\beta$-amyloid carrier proteins like albumin and transthyretin into the brain (Carro et al., 2002). Tumour necrosis factor- $\alpha$, a proinflammatory cytokine possibly related to neurodegeneration 
and ageing, can antagonise this effect. In another important study, endocrine, liver-derived IGF-I improved spatial learning and memory functions in old mice (Svensson et al., 2006).

Since clearance of CNS $\beta$-amyloid by IGF-I has been shown to be effective in a mouse model, clinical trials in humans seemed promising (Carro and Torres-Aleman, 2004, , 2006). However, application of the GH secretagogue MK-677, which is a potent inducer of IGF-I secretion, did not show a clinical effect on the disease progression in patients with AD in a randomised trial (Sevigny et al., 2008). More and detailed data is warranted from ongoing trials, which plan to finally evaluate the efficacy of IGF-I variants as potential AD modifying agents.

\section{Skin and CNS - Is there a connection?}

\subsection{Embryology of skin and CNS}

Neural and epidermal tissues are both ectodermal derivatives. In several organisms, like amphibians and more particular in Xenopus laevis, enormous progress has been made in understanding the way the choice of neural or epidermal fate is determined. During gastrulation the cells of the embryonic ectoderm give rise to epidermal progenitors in the ventral side and neural progenitors in the dorsal side. In 1924, Spemann and Mangold demonstrated that the dorsal mesoderm is able to induce nervous system from the adjacent ectoderm by secreting a source of inducing signal. Recently, signalling molecules, which participate in this embryonic decision have been identified. Induction of epidermis occurs through a signalling cascade involving Bone Morphogenetic Proteins (BMP) 2, 4, 7 and receptor-regulated Smad proteins, which translocate into the nucleus to form active transcriptional complexes. These molecules mediate BMP activation of epidermal-specific gene expression and repression of neural-specific gene transcription. On the other hand, neural fate is induced by factors secreted by the dorsal mesoderm (e.g. noggin, chordin and follistatin), which act by blocking BMP signalling. In addition, it has been shown that calcium plays a key role and it is required for neural determination [Figure 2] (Moreau and Leclerc, 2004).

\subsection{Skin models of ageing as tools for understanding molecular ageing mechanisms of CNS}

Recent data suggest that skin represents an adequate model for ageing research and imply the use of skin samples for evaluating the ageing status of the nervous system. Within the scope of the Explorative Project 'Genetic aetiology of human longevity' supported by the 
German National Genome Research Network 2 (NGFN-2) an in vitro model of human hormonal ageing was developed. Human epithelial cells - SZ95 sebocytes - were maintained under a hormone-substituted environment consisting of growth factors and sexual steroids in concentrations corresponding to those circulating in 20- and in 60-year-old women. Expression profilling employing a cDNA microarray composed of 15,529 cDNA sequences identified 899 genes with altered expression levels in SZ95 sebocytes maintained under the 20- and 60-year-old hormone mixture, respectively. The functional annotation of these genes according to the Gene Ontology identified pathways related to mitochondrial function, oxidative stress, ubiquitine-mediated proteolysis, cell cycle, immune responses, steroid biosynthesis and phospholipid degradation - biological processes which are all hallmarks of the ageing process.

According to the KEGG database, the most significantly altered signalling pathway identified was that of the transforming growth factor- $\beta$ (TGF $\beta$ ). The TGF $\beta$ family consists of multifunctional factors, which regulate many cellular processes, such as differentiation and proliferation of keratinocytes and fibroblasts and the synthesis of extracellular matrix proteins (Massague, 1998). The family members include TGF $\beta$ isoforms, activins and BMPs and propagate the signal through binding to cell surface receptors and phosphorylating Smad proteins. A differential expression of TGF $\beta$ isoforms, activins, BMPs, MADHs / SMADs, and other components of the TGF $\beta$ signalling cascade has been documented in the SZ95 sebocytes under hormone-substituted conditions. As already mentioned above, activation of this pathway represses neural-specific gene transcription in ectodermal cells leading them to epidermal differentiation. The question that arises is to what extent hormones may play a role in the decision of epidermal or neural fate.

In addition, key genes operating in neurodegenerative diseases such as $\mathrm{AD}$ and Parkinson's disease, Huntington's disease, dentatorubral-pallidoluysian atrophy and amyotrophic lateral sclerosis (ALS) have been documented to be expressed in the SZ95 sebocytes and their expression was influenced by the hormone treatment. In particular 24 genes involved in the pathogenesis of AD, among them APP and presenilin-1, were regulated under treatment with growth factors and sex steroids in concentrations corresponding to those circulating in 20 and 60-year-old women, respectively. Though not proven, these results might imply that a disturbed hormone status might induce the regulation of these genes and the generation of neurodegenerative diseases (Makrantonaki et al., 2006).

APP which was initially detected in cells of the CNS has been found also in the epidermis where it fulfils a variety of distinct biological roles. It facilitates keratinocyte adhesion due to 
its ability to interact with the extracellular matrix, it serves as an adapter protein for binding the motor protein kinesin, thereby mediating the centripetal transport of melanosomes in epidermal melanocytes and the soluble N-terminal portion of APP has been shown to be a potent epidermal growth factor thus stimulating proliferation and migration of keratinocytes as well as the exocytic release of melanin by melanocytes (Herzog et al., 2004). The expression of $\beta$-amyloid and tau-protein has been documented in the mast cells of skin in $\mathrm{AD}$ patients, which supports the hypothesis that $\mathrm{AD}$ is a systemic disease involving different organs and tissues (Kvetnoi et al., 2003).

Cutaneous melanocytes have provided a valuable in vitro model for studies of $A D$ and for development of potential therapies. It has been shown that under the presence of $\beta$-amyloid, melanocytes undergo apoptosis, like neurons and the nerve growth factor, which has been reported to attenuate the loss of cholinergic neurons in $\mathrm{AD}$, exerts a protective effect (Yaar and Gilchrest, 1997).

In cultured skin fibroblasts derived from sporadic $\mathrm{AD}$ patients and from age-matched controls the differences in intracellular free calcium levels $\left(\left[\mathrm{Ca}^{2+}\right] \mathrm{i}\right)$ have been investigated. $\mathrm{AD}$ cells exhibited lower $\left[\mathrm{Ca}^{2+}\right] \mathrm{i}$ as compared to the control cultures. Exposure of fibroblasts to $\beta$-amyloid resulted in increased $\left[\mathrm{Ca}^{2+}\right] \mathrm{i}$ of the control cells, but not of $\mathrm{AD}$ fibroblasts (Palotas et al., 2001). Further studies have shown the presence of inflammatory and immunorelated markers in cultured skin fibroblasts from familial (FAD) and sporadic AD patients (Scali et al., 2002). Additionally, fibroblasts from AD patients were more resistant than those from control subjects to $\mathrm{H}_{2} \mathrm{O}_{2}$ treatment, although the extent of DNA damage induced by the oxidative injury was similar in both experimental groups. The protective mechanism of AD fibroblasts was related to an impairment of $\mathrm{H}_{2} \mathrm{O}_{2}$-induced cell cycle arrest and characterised by an accelerated re-entry into the cell cycle and a diminished induction of apoptosis which may be due to a profound impairment in the $\mathrm{H}_{2} \mathrm{O}_{2}$-activated, p53-dependent pathway (Uberti et al., 2002; Uberti et al., 2006).

Compared to controls, the fibroblasts carrying APP and presenilin-1 gene mutations showed a clear increase in lipoperoxidation products, malondialdehyde, and 4hydroxynonenal. The antioxidant defenses of cells from FAD patients were lower than those from normal subjects. Furthermore, ADP ribosylation levels of poly(ADP-ribose) polymerase (PARP) nuclear substrates were significantly raised, whereas the PARP content did not differ significantly between fibroblasts carrying gene mutations and control cells (Cecchi et al., 2002). 
A characteristic feature of AD is the increased Ser phosphorylation of tau microtubuleassociated protein in the brain. In skin fibroblasts derived from persons who have or will develop $\mathrm{AD}$ due to presenilin 1 mutations or trisomy 21, bradykinin (BK) B2 receptor activation leads to selective Ser phosphorylation of tau. This is not the case in skin fibroblasts from normal individuals at any age. This reflects modification of the $\mathrm{G}$ protein-coupled BK B2 receptors themselves suggesting that BK receptor pathway dysfunction may be a molecular signature yielding information about the pathogenesis of AD (Jong et al., 2003). Finally, a disturbed degradation of proteins in lysosomes has been demonstrated not only in CNS but also in peripheral level, in skin fibroblasts from patients affected either by sporadic or familial forms of AD (Urbanelli et al., 2008).

\section{Conclusion}

Skin mirrors the first signs of human ageing due to the accompanying hormone decline. Recent studies have revealed that skin can be used as a model for a better understanding of the global pathogenesis of ageing. The fact that skin shares the same embryologic origin with the nervous system makes it an attractive alternative for exploring the pathways involved in the pathogenesis of neurodegenerative diseases, in particular since the collection of specimens from human brain throughout life for experimental research purposes is associated with major practical and ethical obstacles. The skin and neural tissue have also in common strong influences and dependencies on the endocrine environment. Elucidating the molecular mechanisms involved in the initiation of ageing of these two tissues and the magnitude of hormone contribution would offer immense opportunities for the development of future treatments. 


\section{Acknowledgements}

This work was supported by a BMBF research grant by the German Federal Ministry of Education and Research to C.C.Z. E.M. is grateful for having received the R.O.S.A. Prize (Research on Skin Dryness Award) 2008 and the Beauty Care Prize 2009 from the German Society of Dermatology for her contribution to the investigation of the molecular mechanisms involved in human skin ageing. 


\section{References}

Adashi, E.Y., Resnick, C.E., Svoboda, M.E., Van Wyk, J.J., 1985. Somatomedin-C synergizes with follicle-stimulating hormone in the acquisition of progestin biosynthetic capacity by cultured rat granulosa cells. Endocrinology 116, 2135-42.

Affinito, P., Palomba, S., Sorrentino, C., Di Carlo, C., Bifulco, G., Arienzo, M.P., Nappi, C., 1999. Effects of postmenopausal hypoestrogenism on skin collagen. Maturitas 33, 239-47.

Allsopp, R.C., Vaziri, H., Patterson, C., Goldstein, S., Younglai, E.V., Futcher, A.B., Greider, C.W., Harley, C.B., 1992. Telomere length predicts replicative capacity of human fibroblasts. Proc Natl Acad Sci U S A 89, 10114-8.

Ashcroft, G.S., Horan, M.A., Ferguson, M.W., 1997. The effects of ageing on wound healing: immunolocalisation of growth factors and their receptors in a murine incisional model. $\mathrm{J}$ Anat 190 ( Pt 3), 351-65.

Ashcroft, G.S., Ashworth, J.J., 2003. Potential role of estrogens in wound healing. Am J Clin Dermatol 4, 737-43.

Ashcroft, G.S., Mills, S.J., Flanders, K.C., Lyakh, L.A., Anzano, M.A., Gilliver, S.C., Roberts, A.B., 2003. Role of Smad3 in the hormonal modulation of in vivo wound healing responses. Wound Repair Regen 11, 468-73.

Atwood, C.S., Meethal, S.V., Liu, T., Wilson, A.C., Gallego, M., Smith, M.A., Bowen, R.L., 2005. Dysregulation of the hypothalamic-pituitary-gonadal axis with menopause and andropause promotes neurodegenerative senescence. J Neuropathol Exp Neurol 64, 93-103.

Baulieu, E.E., Thomas, G., Legrain, S., Lahlou, N., Roger, M., Debuire, B., Faucounau, V., Girard, L., Hervy, M.P., Latour, F., Leaud, M.C., Mokrane, A., Pitti-Ferrandi, H., Trivalle, C., de Lacharriere, O., Nouveau, S., Rakoto-Arison, B., Souberbielle, J.C., Raison, J., Le Bouc, Y., Raynaud, A., Girerd, X., Forette, F., 2000. Dehydroepiandrosterone (DHEA), DHEA sulfate, and aging: contribution of the DHEAge Study to a sociobiomedical issue. Proc Natl Acad Sci U S A 97, 4279-84.

Behl, C., Skutella, T., Lezoualc'h, F., Post, A., Widmann, M., Newton, C.J., Holsboer, F., 1997. Neuroprotection against oxidative stress by estrogens: structure-activity relationship. Mol Pharmacol 51, 535-41.

Benn, P.A., 1976. Specific chromosome aberrations in senescent fibroblast cell lines derived from human embryos. Am J Hum Genet 28, 465-73.

Bennett, A.E., Wahner, H.W., Riggs, B.L., Hintz, R.L., 1984. Insulin-like growth factors I and II: aging and bone density in women. J Clin Endocrinol Metab 59, 701-4.

Beral, V., 2003. Breast cancer and hormone-replacement therapy in the Million Women Study. Lancet 362, 419-27.

Bishop, J., Simpkins, J.W., 1995. Estradiol enhances brain glucose uptake in ovariectomized rats. Brain Res Bull 36, 315-20.

Blanche, H., Cabanne, L., Sahbatou, M., Thomas, G., 2001. A study of French centenarians: are ACE and APOE associated with longevity? C R Acad Sci III 324, 129-35.

Bodnar, A.G., Ouellette, M., Frolkis, M., Holt, S.E., Chiu, C.P., Morin, G.B., Harley, C.B., Shay, J.W., Lichtsteiner, S., Wright, W.E., 1998. Extension of life-span by introduction of telomerase into normal human cells. Science 279, 349-52.

Brincat, M.P., 2000. Hormone replacement therapy and the skin. Maturitas 35, 107-17.

Burger, H.G., Dudley, E.C., Cui, J., Dennerstein, L., Hopper, J.L., 2000. A prospective longitudinal study of serum testosterone, dehydroepiandrosterone sulfate, and sex hormonebinding globulin levels through the menopause transition. J Clin Endocrinol Metab 85, 2832-8.

Burton, J.L., Libman, L.J., Cunliffe, W.J., Wilkinson, R., Hall, R., Shuster, S., 1972. Sebum excretion in acromegaly. Br Med J 1, 406-8. 
Callens, A., Vaillant, L., Lecomte, P., Berson, M., Gall, Y., Lorette, G., 1996. Does hormonal skin aging exist? A study of the influence of different hormone therapy regimens on the skin of postmenopausal women using non-invasive measurement techniques. Dermatology 193, 289-94.

Carro, E., Trejo, J.L., Gomez-Isla, T., LeRoith, D., Torres-Aleman, I., 2002. Serum insulinlike growth factor I regulates brain amyloid-beta levels. Nat Med 8, 1390-7.

Carro, E., Torres-Aleman, I., 2004. Insulin-like growth factor I and Alzheimer's disease: therapeutic prospects? Expert Rev Neurother 4, 79-86.

Carro, E., Torres-Aleman, I., 2006. Serum insulin-like growth factor I in brain function. Keio J Med 55, 59-63.

Carro, E., Trejo, J.L., Gerber, A., Loetscher, H., Torrado, J., Metzger, F., Torres-Aleman, I., 2006. Therapeutic actions of insulin-like growth factor I on APP/PS2 mice with severe brain amyloidosis. Neurobiol Aging 27, 1250-7.

Carroll, P.V., Christ, E.R., Bengtsson, B.A., Carlsson, L., Christiansen, J.S., Clemmons, D., Hintz, R., Ho, K., Laron, Z., Sizonenko, P., Sonksen, P.H., Tanaka, T., Thorne, M., 1998. Growth hormone deficiency in adulthood and the effects of growth hormone replacement: a review. Growth Hormone Research Society Scientific Committee. J Clin Endocrinol Metab 83, 382-95.

Cecchi, C., Fiorillo, C., Sorbi, S., Latorraca, S., Nacmias, B., Bagnoli, S., Nassi, P., Liguri, G., 2002. Oxidative stress and reduced antioxidant defenses in peripheral cells from familial Alzheimer's patients. Free Radic Biol Med 33, 1372-9.

Chau, D., Mancoll, J.S., Lee, S., Zhao, J., Phillips, L.G., Gittes, G.K., Longaker, M.T., 1998. Tamoxifen downregulates TGF-beta production in keloid fibroblasts. Ann Plast Surg 40, 490-3.

Chen, W., Yang, C.C., Sheu, H.M., Seltmann, H., Zouboulis, C.C., 2003. Expression of peroxisome proliferator-activated receptor and CCAAT/enhancer binding protein transcription factors in cultured human sebocytes. J Invest Dermatol 121, 441-7.

Chernausek, S.D., Backeljauw, P.F., Frane, J., Kuntze, J., Underwood, L.E., 2007. Long-term treatment with recombinant insulin-like growth factor (IGF)-I in children with severe IGF-I deficiency due to growth hormone insensitivity. J Clin Endocrinol Metab 92, 902-10.

Christensen, K., Johnson, T.E., Vaupel, J.W., 2006. The quest for genetic determinants of human longevity: challenges and insights. Nat Rev Genet 7, 436-48.

Conboy, I.M., Conboy, M.J., Wagers, A.J., Girma, E.R., Weissman, I.L., Rando, T.A., 2005. Rejuvenation of aged progenitor cells by exposure to a young systemic environment. Nature 433, 760-4.

Corpas, E., Harman, S.M., Blackman, M.R., 1993. Human growth hormone and human aging. Endocr Rev 14, 20-39.

D'Ercole, A.J., Stiles, A.D., Underwood, L.E., 1984. Tissue concentrations of somatomedin $\mathrm{C}$ : further evidence for multiple sites of synthesis and paracrine or autocrine mechanisms of action. Proc Natl Acad Sci U S A 81, 935-9.

Deplewski, D., Rosenfield, R.L., 1999. Growth hormone and insulin-like growth factors have different effects on sebaceous cell growth and differentiation. Endocrinology 140, 4089-94.

Dimri, G.P., Lee, X., Basile, G., Acosta, M., Scott, G., Roskelley, C., Medrano, E.E., Linskens, M., Rubelj, I., Pereira-Smith, O., et al., 1995. A biomarker that identifies senescent human cells in culture and in aging skin in vivo. Proc Natl Acad Sci U S A 92, 9363-7.

Dunn, L.B., Damesyn, M., Moore, A.A., Reuben, D.B., Greendale, G.A., 1997. Does estrogen prevent skin aging? Results from the First National Health and Nutrition Examination Survey (NHANES I). Arch Dermatol 133, 339-42.

Duong, T., Nikolaeva, M., Acton, P.J., 1997. C-reactive protein-like immunoreactivity in the neurofibrillary tangles of Alzheimer's disease. Brain Res 749, 152-6. 
Effros, R.B., 2001. Ageing and the immune system. Novartis Found Symp 235, 130-9; discussion 139-45, 146-9.

Elias, P.M., Ghadially, R., 2002. The aged epidermal permeability barrier: basis for functional abnormalities. Clin Geriatr Med 18, 103-20, vii.

Faiman, C., Winter, J.S., 1971. Diurnal cycles in plasma FSH, testosterone and cortisol in men. J Clin Endocrinol Metab 33, 186-92.

Feldman, H.A., Longcope, C., Derby, C.A., Johannes, C.B., Araujo, A.B., Coviello, A.D., Bremner, W.J., McKinlay, J.B., 2002. Age trends in the level of serum testosterone and other hormones in middle-aged men: longitudinal results from the Massachusetts male aging study. J Clin Endocrinol Metab 87, 589-98.

Fernandez-Tresguerres Hernandez, J.A., 2004. [Effects of hormones on aging of the CNS, the immune system and the skin in rats]. An R Acad Nac Med (Madr) 121, 157-76; discussion $176-9$.

Ferri, C.P., Prince, M., Brayne, C., Brodaty, H., Fratiglioni, L., Ganguli, M., Hall, K., Hasegawa, K., Hendrie, H., Huang, Y., Jorm, A., Mathers, C., Menezes, P.R., Rimmer, E., Scazufca, M., 2005. Global prevalence of dementia: a Delphi consensus study. Lancet 366, 2112-7.

Flachsbart, F., Caliebe, A., Kleindorp, R., Blanche, H., von Eller-Eberstein, H., Nikolaus, S., Schreiber, S., Nebel, A., 2009. Association of FOXO3A variation with human longevity confirmed in German centenarians. Proc Natl Acad Sci U S A 106, 2700-5.

Franceschi, C., Bonafe, M., Valensin, S., 2000. Human immunosenescence: the prevailing of innate immunity, the failing of clonotypic immunity, and the filling of immunological space. Vaccine 18, 1717-20.

Fritsch, M., Orfanos, C.E., Zouboulis, C.C., 2001. Sebocytes are the key regulators of androgen homeostasis in human skin. J Invest Dermatol 116, 793-800.

Fuchs, K.O., Solis, O., Tapawan, R., Paranjpe, J., 2003. The effects of an estrogen and glycolic acid cream on the facial skin of postmenopausal women: a randomized histologic study. Cutis 71, 481-8.

Gardner, E.M., Murasko, D.M., 2002. Age-related changes in Type 1 and Type 2 cytokine production in humans. Biogerontology 3, 271-90.

Giacomoni, P.U., Rein, G., 2004. A mechanistic model for the aging of human skin. Micron $35,179-84$.

Giannoulis, M.G., Sonksen, P.H., Umpleby, M., Breen, L., Pentecost, C., Whyte, M., McMillan, C.V., Bradley, C., Martin, F.C., 2006. The effects of growth hormone and/or testosterone in healthy elderly men: a randomized controlled trial. J Clin Endocrinol Metab 91, 477-84.

Gilchrest, B.A., 1982. Age-associated changes in the skin. J Am Geriatr Soc 30, 139-43.

Gilchrest, B.A., 1983. In vitro assessment of keratinocyte aging. J Invest Dermatol 81, 184s-9s.

Gilliver, S.C., Ashcroft, G.S., 2007. Sex steroids and cutaneous wound healing: the contrasting influences of estrogens and androgens. Climacteric 10, 276-88.

Gilliver, S.C., Ruckshanthi, J.P., Atkinson, S.J., Ashcroft, G.S., 2007. Androgens influence expression of matrix proteins and proteolytic factors during cutaneous wound healing. Lab Invest 87, 871-81.

Goyarts, E., Muizzuddin, N., Maes, D., Giacomoni, P.U., 2007. Morphological changes associated with aging: age spots and the microinflammatory model of skin aging. Ann N Y Acad Sci 1119, 32-9.

Gray, A., Feldman, H.A., McKinlay, J.B., Longcope, C., 1991. Age, disease, and changing sex hormone levels in middle-aged men: results of the Massachusetts Male Aging Study. J Clin Endocrinol Metab 73, 1016-25. 
Grubeck-Loebenstein, B., Wick, G., 2002. The aging of the immune system. Adv Immunol 80, 243-84.

Guevara-Aguirre, J., Vasconez, O., Martinez, V., Martinez, A.L., Rosenbloom, A.L., Diamond, F.B., Jr., Gargosky, S.E., Nonoshita, L., Rosenfeld, R.G., 1995. A randomized, double blind, placebo-controlled trial on safety and efficacy of recombinant human insulinlike growth factor-I in children with growth hormone receptor deficiency. J Clin Endocrinol Metab 80, 1393-8.

Guevara-Aguirre, J., Rosenbloom, A.L., Vasconez, O., Martinez, V., Gargosky, S.E., Allen, L., Rosenfeld, R.G., 1997. Two-year treatment of growth hormone (GH) receptor deficiency with recombinant insulin-like growth factor I in 22 children: comparison of two dosage levels and to GH-treated GH deficiency. J Clin Endocrinol Metab 82, 629-33.

Guroff, G., 1993. Nerve growth factor as a neurotrophic agent. Ann N Y Acad Sci 692, 51-9. Guy, R., Ridden, C., Kealey, T., 1996. The improved organ maintenance of the human sebaceous gland: modeling in vitro the effects of epidermal growth factor, androgens, estrogens, 13-cis retinoic acid, and phenol red. J Invest Dermatol 106, 454-60.

Han, V.K., Hill, D.J., Strain, A.J., Towle, A.C., Lauder, J.M., Underwood, L.E., D'Ercole, A.J., 1987. Identification of somatomedin/insulin-like growth factor immunoreactive cells in the human fetus. Pediatr Res 22, 245-9.

Hardman, M.J., Emmerson, E., Clarke, L., Ashcroft, G.S., 2007. Selective estrogen receptor modulators accelerate cutaneous wound healing in ovariectomised female mice. Endocrinology.

Harman, S.M., Metter, E.J., Tobin, J.D., Pearson, J., Blackman, M.R., 2001. Longitudinal effects of aging on serum total and free testosterone levels in healthy men. Baltimore Longitudinal Study of Aging. J Clin Endocrinol Metab 86, 724-31.

Hawkins, M.B., Thornton, J.W., Crews, D., Skipper, J.K., Dotte, A., Thomas, P., 2000. Identification of a third distinct estrogen receptor and reclassification of estrogen receptors in teleosts. Proc Natl Acad Sci U S A 97, 10751-6.

Hayflick, L., 1965. The Limited in Vitro Lifetime of Human Diploid Cell Strains. Exp Cell Res 37, 614-36.

Henderson, V.W., 1997. Estrogen, cognition, and a woman's risk of Alzheimer's disease. Am J Med 103, 11S-18S.

Herzog, V., Kirfel, G., Siemes, C., Schmitz, A., 2004. Biological roles of APP in the epidermis. Eur J Cell Biol 83, 613-24.

Hollis, E.R., 2nd, Lu, P., Blesch, A., Tuszynski, M.H., 2009. IGF-I gene delivery promotes corticospinal neuronal survival but not regeneration after adult CNS injury. Exp Neurol 215, 53-9.

Ida, N., Hartmann, T., Pantel, J., Schroder, J., Zerfass, R., Forstl, H., Sandbrink, R., Masters, C.L., Beyreuther, K., 1996. Analysis of heterogeneous A4 peptides in human cerebrospinal fluid and blood by a newly developed sensitive Western blot assay. J Biol Chem 271, 22908-14.

Ikawa, A., Ishii, Y., Suzuki, K., Yasoshima, A., Suzuki, N., Nakayama, H., Takahashi, S., Doi, K., 2002. Age-related changes in the dorsal skin histology in Mini and Wistar rats. Histol Histopathol 17, 419-26.

Iwamoto, N., Nishiyama, E., Ohwada, J., Arai, H., 1994. Demonstration of CRP immunoreactivity in brains of Alzheimer's disease: immunohistochemical study using formic acid pretreatment of tissue sections. Neurosci Lett 177, 23-6.

Jaffe, A.B., Toran-Allerand, C.D., Greengard, P., Gandy, S.E., 1994. Estrogen regulates metabolism of Alzheimer amyloid beta precursor protein. J Biol Chem 269, 13065-8.

Jensen, M., Schroder, J., Blomberg, M., Engvall, B., Pantel, J., Ida, N., Basun, H., Wahlund, L.O., Werle, E., Jauss, M., Beyreuther, K., Lannfelt, L., Hartmann, T., 1999. Cerebrospinal 
fluid A beta42 is increased early in sporadic Alzheimer's disease and declines with disease progression. Ann Neurol 45, 504-11.

Johnson, J.K., McCleary, R., Oshita, M.H., Cotman, C.W., 1998. Initiation and propagation stages of beta-amyloid are associated with distinctive apolipoprotein $\mathrm{E}$, age, and gender profiles. Brain Res 798, 18-24.

Jong, Y.J., Ford, S.R., Seehra, K., Malave, V.B., Baenziger, N.L., 2003. Alzheimer's disease skin fibroblasts selectively express a bradykinin signaling pathway mediating tau protein Ser phosphorylation. Faseb J 17, 2319-21.

Kanda, N., Watanabe, S., 2005. Regulatory roles of sex hormones in cutaneous biology and immunology. J Dermatol Sci 38, 1-7.

Kosmadaki, M.G., Gilchrest, B.A., 2004. The role of telomeres in skin aging/photoaging. Micron 35, 155-9.

Kvetnoi, I.M., Kvetnaia, T.V., Riadnova, I., Fursov, B.B., Ernandes-Jago, H., Blesa, J.R., 2003. [Expression of beta-amyloid and tau-protein in mastocytes in Alzheimer disease]. Arkh Patol 65, 36-9.

Labrie, F., Belanger, A., Luu-The, V., Labrie, C., Simard, J., Cusan, L., Gomez, J.L., Candas, B., 1998. DHEA and the intracrine formation of androgens and estrogens in peripheral target tissues: its role during aging. Steroids 63, 322-8.

Laron, Z., 2005. Do deficiencies in growth hormone and insulin-like growth factor-1 (IGF-1) shorten or prolong longevity? Mech Ageing Dev 126, 305-7.

Lee, K.S., Oh, K.Y., Kim, B.C., 2000. Effects of dehydroepiandrosterone on collagen and collagenase gene expression by skin fibroblasts in culture. J Dermatol Sci 23, 103-10.

Lener, T., Moll, P.R., Rinnerthaler, M., Bauer, J., Aberger, F., Richter, K., 2006. Expression profiling of aging in the human skin. Exp Gerontol 41, 387-97.

Lewis, D.A., Travers, J.B., Somani, A.K., Spandau, D.F., 2009. The IGF-1/IGF-1R signaling axis in the skin: a new role for the dermis in aging-associated skin cancer. Oncogene.

Li, Y., Liu, L., Barger, S.W., Griffin, W.S., 2003. Interleukin-1 mediates pathological effects of microglia on tau phosphorylation and on synaptophysin synthesis in cortical neurons through a p38-MAPK pathway. J Neurosci 23, 1605-11.

Linton, P.J., Dorshkind, K., 2004. Age-related changes in lymphocyte development and function. Nat Immunol 5, 133-9.

Luine, V.N., 1985. Estradiol increases choline acetyltransferase activity in specific basal forebrain nuclei and projection areas of female rats. Exp Neurol 89, 484-90.

Lustig, R.H., 1994. Sex hormone modulation of neural development in vitro. Horm Behav 28, 383-95.

Ly, D.H., Lockhart, D.J., Lerner, R.A., Schultz, P.G., 2000. Mitotic misregulation and human aging. Science 287, 2486-92.

Makrantonaki, E., Adjaye, J., Herwig, R., Brink, T.C., Groth, D., Hultschig, C., Lehrach, H., Zouboulis, C.C., 2006. Age-specific hormonal decline is accompanied by transcriptional changes in human sebocytes in vitro. Aging Cell 5, 331-44.

Makrantonaki, E., Zouboulis, C.C., 2007a. William J. Cunliffe Scientific Awards. Characteristics and pathomechanisms of endogenously aged skin. Dermatology 214, 352-60.

Makrantonaki, E., Zouboulis, C.C., 2007b. Testosterone metabolism to 5alphadihydrotestosterone and synthesis of sebaceous lipids is regulated by the peroxisome proliferator-activated receptor ligand linoleic acid in human sebocytes. Br J Dermatol 156, 428-32.

Makrantonaki, E., Zouboulis, C.C., 2007c. Molecular mechanisms of skin aging: state of the art. Ann N Y Acad Sci 1119, 40-50.

Makrantonaki, E., Vogel, K., Fimmel, S., Oeff, M., Seltmann, H., Zouboulis, C.C., 2008. Interplay of IGF-I and 17beta-estradiol at age-specific levels in human sebocytes and fibroblasts in vitro. Exp Gerontol 43, 939-46. 
Makrantonaki, E., Zouboulis, C.C., 2009. Androgens and ageing of the skin. Curr Opin Endocrinol Diabetes Obes 16, 240-5.

Marcus, R., Hoffman, A.R., 1998. Growth hormone as therapy for older men and women. Annu Rev Pharmacol Toxicol 38, 45-61.

Massague, J., 1998. TGF-beta signal transduction. Annu Rev Biochem 67, 753-91.

Masters, B.A., Raizada, M.K., 1993. Insulin-like growth factor I receptors and IGF-I actions in neuronal cultures from the brain. Ann N Y Acad Sci 692, 89-101.

Menon, G.K., Feingold, K.R., Moser, A.H., Brown, B.E., Elias, P.M., 1985. De novo sterologenesis in the skin. II. Regulation by cutaneous barrier requirements. J Lipid Res 26, 418-27.

Michikawa, Y., Mazzucchelli, F., Bresolin, N., Scarlato, G., Attardi, G., 1999. Agingdependent large accumulation of point mutations in the human mtDNA control region for replication. Science 286, 774-9.

Miquel, J., 1998. An update on the oxygen stress-mitochondrial mutation theory of aging: genetic and evolutionary implications. Exp Gerontol 33, 113-26.

Mooradian, A.D., 1993a. Antioxidant properties of steroids. J Steroid Biochem Mol Biol 45, 509-11.

Mooradian, A.D., 1993b. Mechanisms of age-related endocrine alterations. Part I. Drugs Aging 3, 81-97.

Moreau, M., Leclerc, C., 2004. The choice between epidermal and neural fate: a matter of calcium. Int J Dev Biol 48, 75-84.

Mullan, M., Crawford, F., Axelman, K., Houlden, H., Lilius, L., Winblad, B., Lannfelt, L., 1992. A pathogenic mutation for probable Alzheimer's disease in the APP gene at the Nterminus of beta-amyloid. Nat Genet 1, 345-7.

Mustafa, A., Lannfelt, L., Lilius, L., Islam, A., Winblad, B., Adem, A., 1999. Decreased plasma insulin-like growth factor-I level in familial Alzheimer's disease patients carrying the Swedish APP 670/671 mutation. Dement Geriatr Cogn Disord 10, 446-51.

Nebel, A., Flachsbart, F., Till, A., Caliebe, A., Blanche, H., Arlt, A., Hasler, R., Jacobs, G., Kleindorp, R., Franke, A., Shen, B., Nikolaus, S., Krawczak, M., Rosenstiel, P., Schreiber, S., 2009. A functional EXO1 promoter variant is associated with prolonged life expectancy in centenarians. Mech Ageing Dev 130, 691-9.

Ohkura, T., Isse, K., Akazawa, K., Hamamoto, M., Yaoi, Y., Hagino, N., 1995. Long-term estrogen replacement therapy in female patients with dementia of the Alzheimer type: 7 case reports. Dementia 6, 99-107.

Orentreich, N., Brind, J.L., Rizer, R.L., Vogelman, J.H., 1984. Age changes and sex differences in serum dehydroepiandrosterone sulfate concentrations throughout adulthood. J Clin Endocrinol Metab 59, 551-5.

Palotas, A., Kalman, J., Laskay, G., Juhasz, A., Janka, Z., Penke, B., 2001. Comparative studies on $[\mathrm{Ca} 2+] \mathrm{i}-\mathrm{level}$ of fibroblasts from Alzheimer patients and control individuals. Neurochem Res 26, 817-20.

Pantel, J., Schroder, J., Jauss, M., Essig, M., Minakaran, R., Schonknecht, P., Schneider, G., Schad, L.R., Knopp, M.V., 1999. Topography of callosal atrophy reflects distribution of regional cerebral volume reduction in Alzheimer's disease. Psychiatry Res 90, 181-92.

Papadakis, M.A., Grady, D., Black, D., Tierney, M.J., Gooding, G.A., Schambelan, M., Grunfeld, C., 1996. Growth hormone replacement in healthy older men improves body composition but not functional ability. Ann Intern Med 124, 708-16.

Patriarca, M.T., Goldman, K.Z., Dos Santos, J.M., Petri, V., Simoes, R.S., Soares, J.M., Jr., Simoes, M.J., Baracat, E.C., 2007. Effects of topical estradiol on the facial skin collagen of postmenopausal women under oral hormone therapy: a pilot study. Eur J Obstet Gynecol Reprod Biol 130, 202-5. 
Petanceska, S.S., Nagy, V., Frail, D., Gandy, S., 2000. Ovariectomy and 17beta-estradiol modulate the levels of Alzheimer's amyloid beta peptides in brain. Exp Gerontol 35, 1317-25. Phillips, T.J., Symons, J., Menon, S., 2008. Does hormone therapy improve age-related skin changes in postmenopausal women? A randomized, double-blind, double-dummy, placebocontrolled multicenter study assessing the effects of norethindrone acetate and ethinyl estradiol in the improvement of mild to moderate age-related skin changes in postmenopausal women. J Am Acad Dermatol 59, 397-404 e3.

Plackett, T.P., Boehmer, E.D., Faunce, D.E., Kovacs, E.J., 2004. Aging and innate immune cells. J Leukoc Biol 76, 291-9.

Plowden, J., Renshaw-Hoelscher, M., Engleman, C., Katz, J., Sambhara, S., 2004. Innate immunity in aging: impact on macrophage function. Aging Cell 3, 161-7.

Pochi, P.E., Strauss, J.S., Downing, D.T., 1979. Age-related changes in sebaceous gland activity. J Invest Dermatol 73, 108-11.

Punnonen, R., Vaajalahti, P., Teisala, K., 1987. Local oestriol treatment improves the structure of elastic fibers in the skin of postmenopausal women. Ann Chir Gynaecol Suppl 202, 39-41.

Qiu, C., De Ronchi, D., Fratiglioni, L., 2007. The epidemiology of the dementias: an update. Curr Opin Psychiatry 20, 380-5.

Riedl, M., Kotzmann, H., Luger, A., 2001. [Growth hormone in the elderly man]. Wien Med Wochenschr 151, 426-9.

Rittie, L., Kang, S., Voorhees, J.J., Fisher, G.J., 2008. Induction of collagen by estradiol: difference between sun-protected and photodamaged human skin in vivo. Arch Dermatol 144, 1129-40.

Robinson, M.K., Binder, R.L., Griffiths, C.E., 2009. Genomic-driven insights into changes in aging skin. J Drugs Dermatol 8, s8-11.

Rosenbloom, A.L., 2009. Mecasermin (recombinant human insulin-like growth factor I). Adv Ther 26, 40-54.

Rosenfield, R.L., Deplewski, D., Kentsis, A., Ciletti, N., 1998. Mechanisms of androgen induction of sebocyte differentiation. Dermatology 196, 43-6.

Rossouw, J.E., Anderson, G.L., Prentice, R.L., LaCroix, A.Z., Kooperberg, C., Stefanick, M.L., Jackson, R.D., Beresford, S.A., Howard, B.V., Johnson, K.C., Kotchen, J.M., Ockene, J., 2002. Risks and benefits of estrogen plus progestin in healthy postmenopausal women: principal results From the Women's Health Initiative randomized controlled trial. Jama 288, 321-33.

Rudman, D., Feller, A.G., Nagraj, H.S., Gergans, G.A., Lalitha, P.Y., Goldberg, A.F., Schlenker, R.A., Cohn, L., Rudman, I.W., Mattson, D.E., 1990. Effects of human growth hormone in men over 60 years old. N Engl J Med 323, 1-6.

Samani, A.A., Yakar, S., LeRoith, D., Brodt, P., 2007. The role of the IGF system in cancer growth and metastasis: overview and recent insights. Endocr Rev 28, 20-47.

Sator, P.G., Schmidt, J.B., Sator, M.O., Huber, J.C., Honigsmann, H., 2001. The influence of hormone replacement therapy on skin ageing: a pilot study. Maturitas 39, 43-55.

Sator, P.G., Sator, M.O., Schmidt, J.B., Nahavandi, H., Radakovic, S., Huber, J.C., Honigsmann, H., 2007. A prospective, randomized, double-blind, placebo-controlled study on the influence of a hormone replacement therapy on skin aging in postmenopausal women. Climacteric 10, 320-34.

Scali, C., Prosperi, C., Bracco, L., Piccini, C., Baronti, R., Ginestroni, A., Sorbi, S., Pepeu, G., Casamenti, F., 2002. Neutrophils CD11b and fibroblasts PGE(2) are elevated in Alzheimer's disease. Neurobiol Aging 23, 523-30.

Schmidt, J.B., 2005. Perspectives of estrogen treatment in skin aging. Exp Dermatol 14, 156. Schneider, E.L., Mitsui, Y., 1976. The relationship between in vitro cellular aging and in vivo human age. Proc Natl Acad Sci U S A 73, 3584-8. 
Schonknecht, P., Lutjohann, D., Pantel, J., Bardenheuer, H., Hartmann, T., von Bergmann, K., Beyreuther, K., Schroder, J., 2002. Cerebrospinal fluid 24S-hydroxycholesterol is increased in patients with Alzheimer's disease compared to healthy controls. Neurosci Lett 324, 83-5.

Schonknecht, P., Pantel, J., Hartmann, T., Werle, E., Volkmann, M., Essig, M., Amann, M., Zanabili, N., Bardenheuer, H., Hunt, A., Schroder, J., 2003. Cerebrospinal fluid tau levels in Alzheimer's disease are elevated when compared with vascular dementia but do not correlate with measures of cerebral atrophy. Psychiatry Res 120, 231-8.

Schonknecht, P., Pantel, J., Kruse, A., Schroder, J., 2005. Prevalence and natural course of aging-associated cognitive decline in a population-based sample of young-old subjects. Am J Psychiatry 162, 2071-7.

Schonknecht, P., Pantel, J., Kaiser, E., Thomann, P., Schroder, J., 2007. Increased tau protein differentiates mild cognitive impairment from geriatric depression and predicts conversion to dementia. Neurosci Lett 416, 39-42.

Sevigny, J.J., Ryan, J.M., van Dyck, C.H., Peng, Y., Lines, C.R., Nessly, M.L., 2008. Growth hormone secretagogue MK-677: no clinical effect on AD progression in a randomized trial. Neurology 71, 1702-8.

Shin, M.H., Rhie, G.E., Park, C.H., Kim, K.H., Cho, K.H., Eun, H.C., Chung, J.H., 2005. Modulation of collagen metabolism by the topical application of dehydroepiandrosterone to human skin. J Invest Dermatol 124, 315-23.

Shumaker, S.A., Legault, C., Kuller, L., Rapp, S.R., Thal, L., Lane, D.S., Fillit, H., Stefanick, M.L., Hendrix, S.L., Lewis, C.E., Masaki, K., Coker, L.H., 2004. Conjugated equine estrogens and incidence of probable dementia and mild cognitive impairment in postmenopausal women: Women's Health Initiative Memory Study. Jama 291, 2947-58.

Singh, R., Kolvraa, S., Rattan, S.I., 2007. Genetics of human longevity with emphasis on the relevance of HSP70 as candidate genes. Front Biosci 12, 4504-13.

Smith, J.R., Pereira-Smith, O.M., 1996. Replicative senescence: implications for in vivo aging and tumor suppression. Science 273, 63-7.

Smyth, C.D., Gosden, R.G., McNeilly, A.S., Hillier, S.G., 1994. Effect of inhibin immunoneutralization on steroidogenesis in rat ovarian follicles in vitro. J Endocrinol 140, $437-43$

Smythe, C.D., Greenall, M., Kealey, T., 1998. The activity of HMG-CoA reductase and acetyl-CoA carboxylase in human apocrine sweat glands, sebaceous glands, and hair follicles is regulated by phosphorylation and by exogenous cholesterol. J Invest Dermatol 111, 139-48. Sumino, H., Ichikawa, S., Abe, M., Endo, Y., Nakajima, Y., Minegishi, T., Ishikawa, O., Kurabayashi, M., 2004. Effects of aging and postmenopausal hypoestrogenism on skin elasticity and bone mineral density in Japanese women. Endocr J 51, 159-64.

Svensson, J., Diez, M., Engel, J., Wass, C., Tivesten, A., Jansson, J.O., Isaksson, O., Archer, T., Hokfelt, T., Ohlsson, C., 2006. Endocrine, liver-derived IGF-I is of importance for spatial learning and memory in old mice. J Endocrinol 189, 617-27.

Tan, Z.S., Seshadri, S. 2010, Inflammation in the Alzheimer's disease cascade: culprit or innocent bystander? Alzheimers Res Ther 2, 6.

Tan, Z.S., Beiser, A.S., Vasan, R.S., Roubenoff, R., Dinarello, C.A., Harris, T.B., Benjamin, E.J., Au, R., Kiel, D.P., Wolf, P.A., Seshadri, S., 2007. Inflammatory markers and the risk of Alzheimer disease: the Framingham Study. Neurology 68, 1902-8.

Tang, M.X., Jacobs, D., Stern, Y., Marder, K., Schofield, P., Gurland, B., Andrews, H., Mayeux, R., 1996. Effect of oestrogen during menopause on risk and age at onset of Alzheimer's disease. Lancet 348, 429-32.

Tavakkol, A., Elder, J.T., Griffiths, C.E., Cooper, K.D., Talwar, H., Fisher, G.J., Keane, K.M., Foltin, S.K., Voorhees, J.J., 1992. Expression of growth hormone receptor, insulin-like growth factor 1 (IGF-1) and IGF-1 receptor mRNA and proteins in human skin. J Invest Dermatol 99, 343-9. 
Tavakkol, A., Varani, J., Elder, J.T., Zouboulis, C.C., 1999. Maintenance of human skin in organ culture: role for insulin-like growth factor-1 receptor and epidermal growth factor receptor. Arch Dermatol Res 291, 643-51.

Tham, A., Sparring, K., Bowen, D., Wetterberg, L., Sara, V.R., 1988. Insulin-like growth factors and somatomedin B in the cerebrospinal fluid of patients with dementia of the Alzheimer type. Acta Psychiatr Scand 77, 719-23.

Thienhaus, O.J., Zemlan, F.P., Bienenfeld, D., Hartford, J.T., Bosmann, H.B., 1987. Growth hormone response to edrophonium in Alzheimer's disease. Am J Psychiatry 144, 1049-52.

Thornton, M.J., Nelson, L.D., Taylor, A.H., Birch, M.P., Laing, I., Messenger, A.G., 2006. The modulation of aromatase and estrogen receptor alpha in cultured human dermal papilla cells by dexamethasone: a novel mechanism for selective action of estrogen via estrogen receptor beta? J Invest Dermatol 126, 2010-8.

Tomlinson, J.W., Holden, N., Hills, R.K., Wheatley, K., Clayton, R.N., Bates, A.S., Sheppard, M.C., Stewart, P.M., 2001. Association between premature mortality and hypopituitarism. West Midlands Prospective Hypopituitary Study Group. Lancet 357, 425-31. Tresini, M., Lorenzini, A., Torres, C., Cristofalo, V.J., 2007. Modulation of replicative senescence of diploid human cells by nuclear ERK signaling. J Biol Chem 282, 4136-51.

Tsukahara, K., Kakuo, S., Moriwaki, S., Hotta, M., Ohuchi, A., Kitahara, T., Harada, N., 2008. The characteristics of aromatase deficient hairless mice indicate important roles of extragonadal estrogen in the skin. J Steroid Biochem Mol Biol 108, 82-90.

Uberti, D., Carsana, T., Bernardi, E., Rodella, L., Grigolato, P., Lanni, C., Racchi, M., Govoni, S., Memo, M., 2002. Selective impairment of p53-mediated cell death in fibroblasts from sporadic Alzheimer's disease patients. J Cell Sci 115, 3131-8.

Uberti, D., Lanni, C., Carsana, T., Francisconi, S., Missale, C., Racchi, M., Govoni, S., Memo, M., 2006. Identification of a mutant-like conformation of p53 in fibroblasts from sporadic Alzheimer's disease patients. Neurobiol Aging 27, 1193-201.

Urabe, M., Yamamoto, T., Kashiwagi, T., Okubo, T., Tsuchiya, H., Iwasa, K., Kikuchi, N., Yokota, K., Hosokawa, K., Honjo, H., 1996. Effect of estrogen replacement therapy on hepatic triglyceride lipase, lipoprotein lipase and lipids including apolipoprotein $\mathrm{E}$ in climacteric and elderly women. Endocr J 43, 737-42.

Urbanelli, L., Emiliani, C., Massini, C., Persichetti, E., Orlacchio, A., Pelicci, G., Sorbi, S., Hasilik, A., Bernardi, G., Orlacchio, A., 2008. Cathepsin D expression is decreased in Alzheimer's disease fibroblasts. Neurobiol Aging 29, 12-22.

van Exel, E., Eikelenboom, P., Comijs, H., Frolich, M., Smit, J.H., Stek, M.L., Scheltens, P., Eefsting, J.E., Westendorp, R.G., 2009. Vascular factors and markers of inflammation in offspring with a parental history of late-onset Alzheimer disease. Arch Gen Psychiatry 66, 1263-70.

Vance, M.L., 2003. Can growth hormone prevent aging? N Engl J Med 348, 779-80.

Veldhuis, J.D., Anderson, S.M., Kok, P., Iranmanesh, A., Frystyk, J., Orskov, H., Keenan, D.M., 2004. Estradiol supplementation modulates growth hormone (GH) secretory-burst waveform and recombinant human insulin-like growth factor-I-enforced suppression of endogenously driven GH release in postmenopausal women. J Clin Endocrinol Metab 89, $1312-8$.

Willcox, B.J., Donlon, T.A., He, Q., Chen, R., Grove, J.S., Yano, K., Masaki, K.H., Willcox, D.C., Rodriguez, B., Curb, J.D., 2008. FOXO3A genotype is strongly associated with human longevity. Proc Natl Acad Sci U S A 105, 13987-92.

Wilson, C.J., Finch, C.E., Cohen, H.J., 2002. Cytokines and cognition--the case for a head-totoe inflammatory paradigm. J Am Geriatr Soc 50, 2041-56.

Woolley, C.S., McEwen, B.S., 1994. Estradiol regulates hippocampal dendritic spine density via an N-methyl-D-aspartate receptor-dependent mechanism. J Neurosci 14, 7680-7. 
Xu, H., Gouras, G.K., Greenfield, J.P., Vincent, B., Naslund, J., Mazzarelli, L., Fried, G., Jovanovic, J.N., Seeger, M., Relkin, N.R., Liao, F., Checler, F., Buxbaum, J.D., Chait, B.T., Thinakaran, G., Sisodia, S.S., Wang, R., Greengard, P., Gandy, S., 1998. Estrogen reduces neuronal generation of Alzheimer beta-amyloid peptides. Nat Med 4, 447-51.

Yaar, M., Gilchrest, B.A., 1997. Human melanocytes as a model system for studies of Alzheimer disease. Arch Dermatol 133, 1287-91.

Yaffe, K., Sawaya, G., Lieberburg, I., Grady, D., 1998. Estrogen therapy in postmenopausal women: effects on cognitive function and dementia. Jama 279, 688-95.

Ye, J., Garg, A., Calhoun, C., Feingold, K.R., Elias, P.M., Ghadially, R., 2002. Alterations in cytokine regulation in aged epidermis: implications for permeability barrier homeostasis and inflammation. I. IL-1 gene family. Exp Dermatol 11, 209-16.

Zouboulis, C.C., 2000. Human skin: an independent peripheral endocrine organ. Horm Res $54,230-42$.

Zouboulis, C.C., Chen, W.C., Thornton, M.J., Qin, K., Rosenfield, R., 2007. Sexual hormones in human skin. Horm Metab Res 39, 85-95.

Zouboulis Ch, C., 2003. [Intrinsic skin aging. A critical appraisal of the role of hormones]. Hautarzt 54, 825-32. 
Table I: Effects of hormone replacement therapy (HRT) in skin

\begin{tabular}{|c|c|c|}
\hline Hormone treatment & Skin effects & Authors \\
\hline $\begin{array}{l}\text { - } 21 \text { men } 61 \text { to } 81 \text { years old with serum IGF-I concentrations } \\
\text { less than } 350 \mathrm{U} / \mathrm{lt} \text { participated in a vehicle-controlled clinical } \\
\text { study with ca. } 0.03 \mathrm{mg} / \mathrm{kg} \text { BW recombinant biosynthetic } \\
\text { human growth hormone per kilogram subcutaneously three } \\
\text { times a week treatment. }\end{array}$ & $\begin{array}{l}\text { After } 12 \text { months treatment period skin } \\
\text { thickness increased. }\end{array}$ & (Rudman et al., 1990) \\
\hline $\begin{array}{l}65 \text { patients applied a creme containing } 0,01 \% \text { estradiol or } \\
15 \% \text { glycolic acid alone or in combination to one side of the } \\
\text { face and a vehicle creme to the opposite side. }\end{array}$ & $\begin{array}{l}\text { After } 6 \text { months estradiol treatment } 23 \% \\
\text { increase of epidermal skin thickness was } \\
\text { documented in contrast to control. The } \\
\text { combination of estradiol and glycolic acid } \\
\text { treatment resulted in } 38 \% \text { increase of } \\
\text { epidermal skin thickness. }\end{array}$ & (Fuchs et al., 2003) \\
\hline $\begin{array}{l}\text { - } 40 \text { postmenopausal women and } 30 \text { age-matched men (mean } \\
\text { age of both } 75 \text { years) with photodamaged skin underwent } \\
\text { estradiol and vehicle extern treatment on light-protected hip } \\
\text { or photodamaged forearm skin }(0,01 \%-2,5 \%, 3 \text { times, every } \\
\text { other day). } \\
5 \text { males and } 5 \text { females were treated with } 0,2 \% \text { estradiol } \\
\text { creme } 2 \text { times per day on the face. }\end{array}$ & $\begin{array}{l}\text { After } 2 \text { weeks treatment induction of } \\
\text { procollagen I and III mRNA and collagen I } \\
\text { protein only in light-protected hip skin, but } \\
\text { not in photoaged forearm and face skin. }\end{array}$ & (Rittie et al., 2008) \\
\hline $\begin{array}{l}\text { Postmenopausal women (mean age } 51.3 \text { years) with no } \\
\text { menses for at least } 12 \text { months using oral or transdermal } \\
\text { estrogen therapy for at least } 1 \text { year were treated with topical } \\
0.01 \% \text { micronized } 17 \beta \text {-estradiol gel on the facial skin once a } \\
\text { day for } 16 \text { weeks. }\end{array}$ & $\begin{array}{l}\text { After a 16-week treatment a significant } \\
\text { increase in the epithelial and dermal } \\
\text { thickness and in the amount of collagen was } \\
\text { documented. }\end{array}$ & (Patriarca et al., 2007) \\
\hline - In a pilot study, the effects of three different HRT regimes & - $\quad$ After 6-months hormone treatment & (Sator et al., 2001) \\
\hline
\end{tabular}




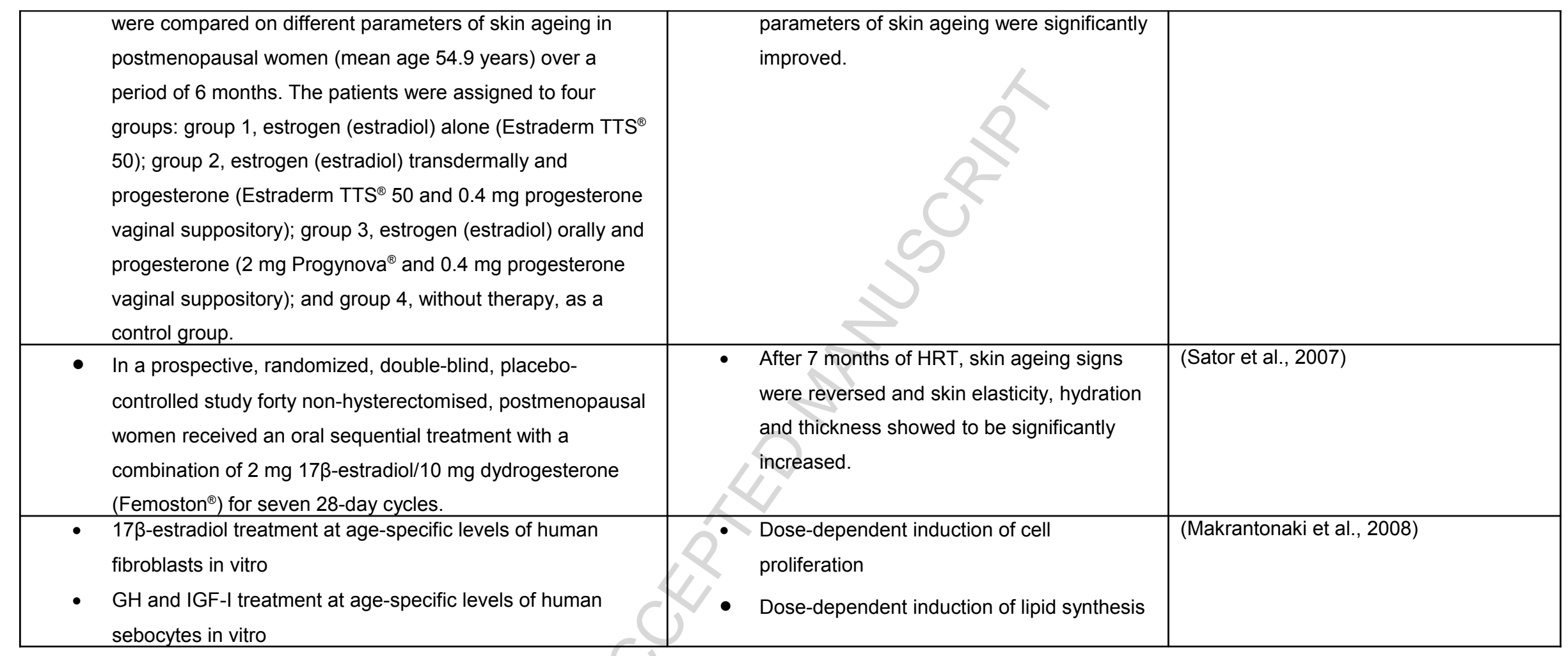


Table II: Effects of growth factors decline

- Reduction of skin thickness

- Loss of dermal collagen, wrinkles

- Increase of subcutaneous adipose tissue

- Small-sized sebaceous glands, reduction of sebum production, skin dryness

- Development of ageing-related non-melanoma skin cancer

- Obesity

- Osteopenia

- Decrease of muscle strength

- Lowered venous access

- Cardiovascular diseases

- Hypercholesterolemia

- $\quad \beta$-amyloid accumulation in animal models

- $\quad$ AD phenotype in patients with Swedish amyloid precursor protein (APP) mutation

- $\quad$ Premature mortality 
Table III: Effects of hormone-replacement therapy in CNS

\begin{tabular}{|c|c|c|}
\hline Hormone treatment & CNS effects & Authors \\
\hline $\begin{array}{l}\text { Postmenopausal woman were treated with ERT } \\
\text { (estrogen replacement therapie), which was arranged as } \\
\text { follows: day } 0 \text { to } 21,0.625 \text { to } 1.25 \mathrm{mg} / \text { day conjugated } \\
\text { estrogen (CE); day } 22 \text { to } 28 \text {, no hormone treatment. } 2.5 \\
\text { mg/day medroxyprogesterone acetate (MPA) was also } \\
\text { given or not on days } 11 \text { to } 21 \text { of ERT. } \\
\text { Serum samples were measured within } 6 \text { days after } \\
\text { finished ERT. }\end{array}$ & $\begin{array}{l}\text { Reduction of hepatic triglyceride lipase, total } \\
\text { cholesterol, LDL-cholesterol, apolipoprotein B, } \\
\text { and especially apolipoprotein E serum levels. } \\
\text { - Apolipoprotein E serum level were higher in } \\
\text { cases with < } 20 \mathrm{pg} / \mathrm{ml} \text { of serum } 17 \beta \text {-estradiol } \\
\text { No significant effect on post heparin plasma } \\
\text { lipases and lipid levels after MPA addition. }\end{array}$ & (Urabe et al., 1996) \\
\hline $\begin{array}{l}\text { Women's Health Initiative Memory Study (WHIMS): } \\
\text { Randomized, double-blind and placebo-controlled clinical } \\
\text { trials in } 65 \text { to } 79 \text { years old postmenopausal women } \\
\text { treated with conjugated equine estrogens } 0,626 \mathrm{mg} / \mathrm{d} \\
\text { (CEE) with medroxyprogesteron acetate } 2,5 \mathrm{mg} / \mathrm{d} \text { (MPA) } \\
\text { for } 7 \text { years or CEE alone for } 9 \text { years. }\end{array}$ & $\begin{array}{l}\text { sed risk of both dementia and mild } \\
\text { ive impairment }\end{array}$ & (Shumaker et al., 2004) \\
\hline $\begin{array}{l}\text { - In a doubled-blind, multicenter, placebo-controlled study } \\
563 \text { male an female patients with mild to moderate AD at } \\
\text { age of at least } 50 \text { years received } 25 \text { mg of the growth } \\
\text { hormone secretagogue MK- } 677 \text { (ibutamoren mesylate) } \\
\text { for } 12 \text { months. }\end{array}$ & $\begin{array}{l}\text { - } \begin{array}{l}\text { Treatment did not show a significant clinical } \\
\text { effect on the AD progression }\end{array} \\
\text { - } \quad \text { IGF-I serum levels were strong increased. }\end{array}$ & (Sevigny et al., 2008) \\
\hline - ZR-75-1 cells (human breast carcinoma cell line) were & - Induction of soluble Alzheimer amyloid precursor & (Jaffe et al., 1994) \\
\hline
\end{tabular}




\begin{tabular}{|c|c|c|}
\hline $\begin{array}{l}\text { preincubated with complete medium containing } 1,8 \times 10^{-9} \\
\text { M } 17 \beta \text {-estradiol (comparable concentration with that } \\
\text { expressed at the peak of the human menstrual cycle). } \\
\text { - After } 9 \text { days the medium was replaced with serum-free } \\
\text { medium containing } 1,8 \times 10^{-9} \mathrm{M} 17 \beta \text {-estradiol and the } \\
\text { cells were incubated for additional } 40 \mathrm{~h} \text {. }\end{array}$ & $\begin{array}{l}\text { protein (sAPP). } \\
\text { No significant effect on intracellular immature or } \\
\text { mature APP. }\end{array}$ & \\
\hline $\begin{array}{l}\text { N2a cells (mouse neuroblastoma cell line) were treated } \\
\text { with } 17 \beta \text {-estradiol in various concentrations for } 7 \text { days. } \\
17 \beta \text {-estradiol treatment in rat and mouse (200nM for } \\
7-10 \text { and } 5 \text { days) and human (several concentrations for } \\
7-10 \text { days) embryonic primary neuronal cells. }\end{array}$ & $\begin{array}{l}\text { - Reduction of } A \beta \text {-amyloid release (f.e. } A \beta 1-40 \text {, } \\
1-42,11-40)\end{array}$ & (Xu et al., 1998) \\
\hline $\begin{array}{l}\text { - Ovariectomised female guinea pigs received soy-free } \\
\text { food supplemented with either } 1 \text { or } 5 \mathrm{mg} / 1 \mathrm{~kg} \mathrm{BW} / \text { day } \\
17 \beta \text {-estradiol for } 10 \text { days }\end{array}$ & $\begin{array}{l}\text { - Increase of total brain } A \beta \text { levels in non treated } \\
\text { ovariectomised animals and reversal after } 17 \beta \text { - } \\
\text { estradiol treatment. } \\
\text { No significant differences between low and high } \\
\text { concentration. }\end{array}$ & (Petanceska et al., 2000) \\
\hline $\begin{array}{l}\text { Rat primary hippocampal neurons and mouse clonal } \\
\text { hippocampal } \mathrm{HT} 22 \text { cells incubated as follows: } \\
\text { Pretreatment for } 20 \mathrm{~h} \text { with } 10 \mu \mathrm{M} 17-\beta \text {-estradiol, estriol, } \\
\text { or estrone and } 17-\alpha \text {-estradiol and treatment with } \mathrm{A}_{25-35} \\
(2 \mu \mathrm{M}) \text { for } 24 \mathrm{~h} \text { or } \mathrm{H}_{2} \mathrm{O}_{2}(30 \mu \mathrm{M} \text { or } 60 \mu \mathrm{M}) \text { and } \mathrm{BSO}(500 \\
\mu \mathrm{M}) \\
\text { - Mouse primary cortical neurons and } \mathrm{HT} 22 \text { cells were } \\
\text { pretreated for } 20 \mathrm{~h} \text { with } 1 \mu \mathrm{M} \text { and } 10 \mu \mathrm{M} 17 \text { - } \alpha \text {-Estradiol, }\end{array}$ & $\begin{array}{l}\text { Estrogens and estrogen derivatives with an } \\
\text { intact 3-OH group on the A ring elucidated a } \\
\text { neuroprotective antioxidant role in an estrogen } \\
\text { receptor independent way. }\end{array}$ & (Behl et al., 1997) \\
\hline
\end{tabular}




\begin{tabular}{|c|c|c|}
\hline $\begin{array}{l}\text { ethinyl estradiol, quinestrol, mestranol, 2-OH-estradiol } \\
\text { and 4-OH-estradiol and then treated with } 500 \mu \mathrm{M} \mathrm{BSO} \\
\text { and } 30 \mu \mathrm{M} \mathrm{H} \mathrm{H}_{2} \mathrm{O}_{2} \text { or } 1000 \mu \mathrm{M} \text { glutamate and } 60 \mu \mathrm{M} \mathrm{H}_{2} \mathrm{O}_{2} \\
\text { respectively. } \\
\text { Postnatal rats organotypic hippocampal slice cultures } \\
\text { were pretreated with either } 10 \mu \mathrm{M} \text { mestranol, quinestrol, } \\
\text { or ethinyl estradiol. After } 20 \mathrm{~h} \text { followed a challenge with } \\
250 \mu \mathrm{M} \mathrm{H} \mathrm{O}_{2} \text { for } 24 \mathrm{~h} \text {. }\end{array}$ & & \\
\hline $\begin{array}{l}\text { - Aging Wistar rats were chronic subcutaneously injected } \\
\text { with IGF-I ( } 50 \mathrm{mg} / \mathrm{kg} \text { ). } \\
\text { - } \text { Liver-specific IGF-I-deficient (LID) mice with decreased } \\
\text { serum IGF-I levels of } 60 \% \text {. } \\
\text { Tg2576 mice overexpressing human APP695 were } \\
\text { treated with IGF-I for a month. } \\
\text { B Biotinylated A } \beta_{1-40}(60 \mathrm{nM}) \text { was injected in the cerebral } \\
\text { cortex of young adult rats two days after pretreated with } \\
\text { IGF-I }(10 \mu \mathrm{\mu g} / \text { rat) intracarotid injection. } \\
\text { IGF-I }\left(1 \times 10^{-7} \mathrm{M}\right) \text { was added in rat choroid plexus } \\
\text { cultures, which is a doubled chamber, imitates the blood- } \\
\text { cerebrospinal fluid interface. }\end{array}$ & $\begin{array}{l}\text { Reduced } A \beta \text { burdens in the brain tissue after } \\
\text { IGF-I treatment. } \\
\text { IGF-I stimulated clearance of brain A } \beta \text { probably } \\
\text { via carrier proteins (albumin and transthyretin). } \\
\text { TNF- } \alpha \text { blockaded this induction. }\end{array}$ & (Carro et al., 2002) \\
\hline $\begin{array}{l}\text { - Young (6 months old) and old (18 months old) LI-IGF-I } \text { I- }^{-1} \\
\text { mice, with inactivation of the liver-specific, inducible } \\
\text { production of IGF-I, via the Cre-LoxP conditional } \\
\text { knockout system. }\end{array}$ & $\begin{array}{l}\text { Decline of about } 80 \% \text { of serum IGF-I levels in LI- } \\
\text { IGF-I }{ }^{-1} \text { mice compared to control mice. } \\
\text { - Reduction of spatial working and reference } \\
\text { memory in old LI-IGF-I }{ }^{-1} \text { mice. } \\
\text { - Increased enkephalin and dynorphin }\end{array}$ & (Svensson et al., 2006) \\
\hline
\end{tabular}




\begin{tabular}{|l|l|l|}
\hline & $\begin{array}{l}\text { immunoreactivity and decreased mRNA levels in } \\
\text { hippocampus, elevated astrocytosis and } \\
\text { metabotropic glutamate receptor } 7 \mathrm{a}-\end{array}$ \\
& $\begin{array}{l}\text { immunoreactivity in old LI-IGF-1 } \\
\text { compared to control mice. }\end{array}$ & \\
\hline
\end{tabular}




\section{Figure Legends}

\section{Figure 1}

Expression of growth factors and sex steroid receptors in human skin.

Human skin cells possess a great number of growth factors and sex steroid hormone receptors. Inbalances of the microendocrine environment may lead to various morphological and physiological disturbances in skin with age (summarised on the right).

[GHR: growth hormone receptor, IGF-IR: insulin-like growth factor I, AR: androgen receptor, ER: estrogen receptor, PR: progesterone receptor, PPAR: peroxisome-proliferation activated receptor, ECM: extracellular matrix]
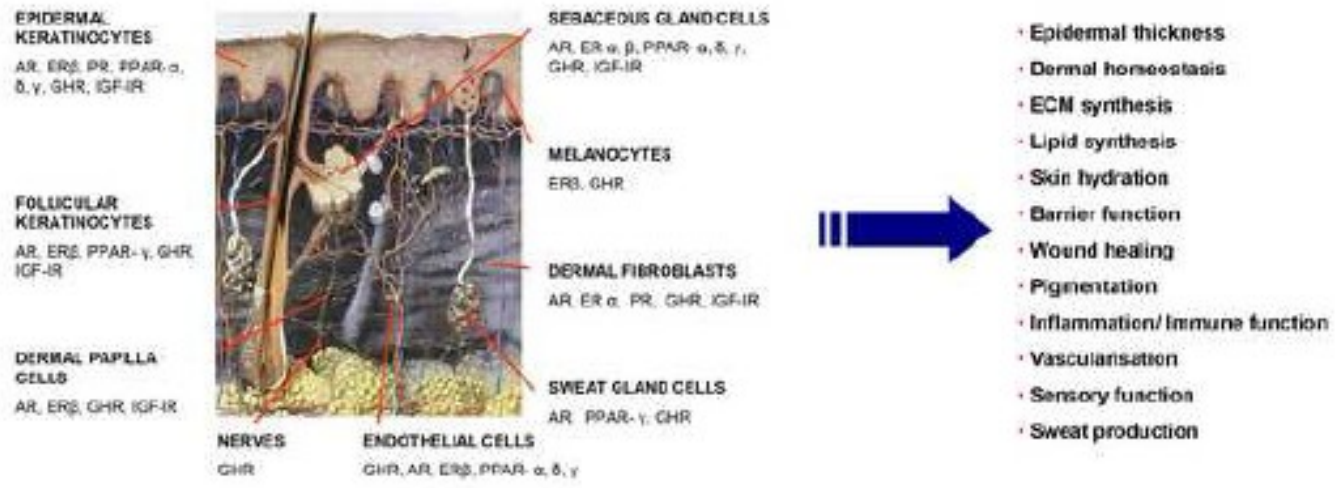


\section{Figure 2}

A schematic overview of epidermal and neural induction in Xenopus laevis embryo.

Epidermal and neural tissue share the same embryological origin. The activation of BMP pathways leads to the formation of a complex between phosphorylated Smad1 and Smad4. After translocation of the complex into the nucleus DNA binding sites such as Msx1, Vent and Gatal are activated, which in turn induce epidermal gene expression and represse neural gene transcription ( green dots). The neural fate is determined by inducers such as noggin, chordin and follistatin (red dots), which prevent binding of BMPs to its receptors and block the BMP signalling pathway.

[BMP: bone morphogenetic proteins, BMPR: bone morphogenetic protein receptors]

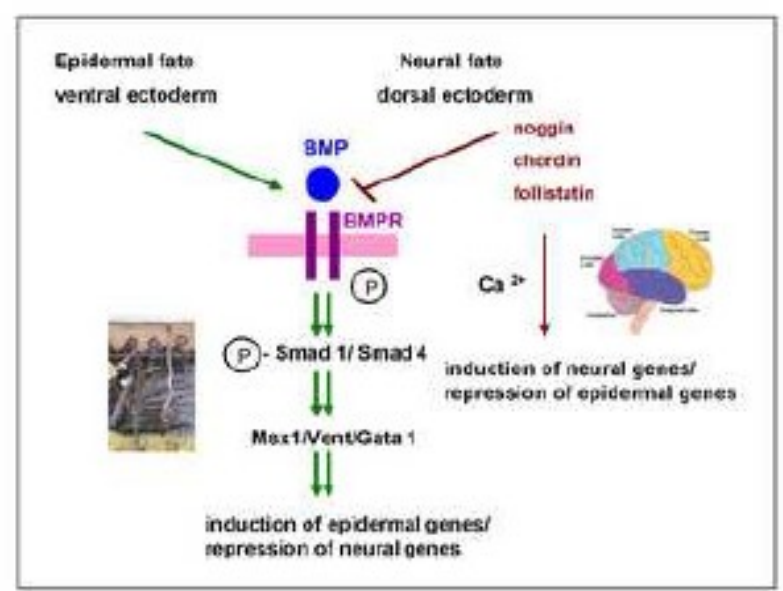

